\title{
Current Status and Prospects of High-Power Fiber Laser Technology (Invited Paper)
}

\author{
Youngchul Kwon ${ }^{1}$, Kyoungyoon Park ${ }^{1}$, Dongyeul Lee ${ }^{1}$, Hanbyul Chang ${ }^{1}$, Seungjong Lee ${ }^{1}$, \\ Luis Alonso Vazquez-Zuniga ${ }^{1}$, Yong Soo Lee ${ }^{2}$, Dong Hwan Kim², \\ Hyun Tae $\mathrm{Kim}^{2}$, and Yoonchan Jeong ${ }^{1 \dagger}$ \\ ${ }^{1}$ Department of Electrical and Computer Engineering, Seoul National University, \\ Gwanak-Gu, Seoul 08826, Korea \\ ${ }^{2}$ Laser Team, Doosan DST, 10, Suji-ro 112beon-gil, Suji-gu, Yongin-si, Gyeonggi-do 16858, Korea
}

(Received December 14, 2015; Revised manuscript February 3, 2016; Accepted February 3, 2016)

\begin{abstract}
Over the past two decades, fiber-based lasers have made remarkable progress, now having reached power levels exceeding kilowatts and drawing a huge amount of attention from academy and industry as a replacement technology for bulk lasers. In this paper we review the significant factors that have led to the progress of fiber lasers, such as gain-fiber regimes based on ytterbium-doped silica, optical pumping schemes through the combination of laser diodes and double-clad fiber geometries, and tandem schemes for minimizing quantum defects. Furthermore, we discuss various power-limitation issues that are expected to incur with respect to the ultimate power scaling of fiber lasers, such as efficiency degradation, thermal hazard, and system-instability growth in fiber lasers, and various relevant methods to alleviate the aforementioned issues. This discussion includes fiber nonlinear effects, fiber damage, and modal-instability issues, which become more significant as the power level is scaled up. In addition, we also review beam-combining techniques, which are currently receiving a lot of attention as an alternative solution to the power-scaling limitation of high-power fiber lasers. In particular, we focus more on the discussion of the schematics of a spectral beam-combining system and their individual requirements. Finally, we discuss prospects for the future development of fiber laser technologies, for them to leap forward from where they are now, and to continue to advance in terms of their power scalability.
\end{abstract}

Keywords: Fiber, Optical amplifier, Laser, Stimulated Brilloin scattering, Beam combination OCIS codes: (140.3280) Laser amplifiers; (140.3298) Laser beam combining; (140.3510) Lasers, fiber; (140.3615) Lasers, ytterbium; (290.5830) Scattering, Brillouin

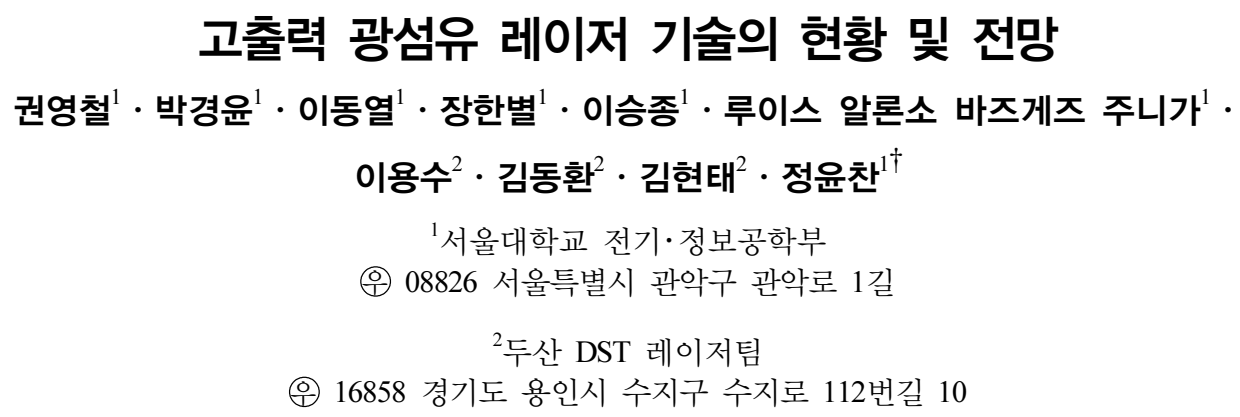

최근 20 여년간의 괄목할만한 발전을 통해 단일 광섬유 레이저의 출력은 이미 $\mathrm{kW}$ 수준을 상회하고 있으며, 기존의 벌크 방식 레이저의 대체 기술로서 여전히 학계 및 산업계의 뜨거운 관심을 받고 있다. 본 논문은 이와 같은 광섬유 레이저의 괄목할만한 성장을 가능하게 한, 이터븀(Ytterbium) 혼입 이득 광섬유 사용 방식, 레이저 다이오드 펌프와 이중 클래딩 광섬유 구조를 통한 광학적 펌프 방식, 더 나아가서 양자결함을 최소화 하는 종렬 펌핑 방식 등 그 주요 요소 기술들을 개괄하고, 그 극한적 고출력화 에 따른 발진 효율 및 특성 저하, 시스템 열화 및 불안정성 증대 등과 같은 고출력 광섬유 레이저 기술 자체가 직면하고 있는

${ }^{\dagger}$ E-mail: yoonchan@snu.ac.kr

Also with Inter-university Semiconductor Research Center \& Institute of Applied Physics, Seoul National University Color versions of one or more of the figures in this paper are available online. 
다양한 기술적 문제점 및 그 완화 방안을 논의한다. 여기에서는 광섬유 레이저의 고출력화와 더불어 야기되는 다양한 형태의 광섬유내 비선형 현상, 광섬유 손상 및 모드 불안정 현상에 대한 논의를 포함한다. 이와 더불어, 전술한 다양한 출력 제한 현상을 극복함과 동시에 광섬유 레이저의 출력을 현격한 수준으로 더욱 증가시키기 위한 대체 방안으로 최근 주목을 많이 받고 있는 다중 빔 결합 기술에 대해 개괄적으로 논의한다. 특히, 분광형 다중 빔 결합 기술의 개념적 시스템 구성 요소 및 각 부문별 요구 기술에 대해 보다 심화된 논점을 둔다. 최종적으로 현 수준을 뛰어 넘는 광섬유 레이저의 출력 증대와 본 기술의 지속적 발전을 위한 앞으로의 발전 방향을 논의한다.

Keywords: 광섬유, 광증폭기, 레이저, 유도 브릴루앙 산란, 빔 결합

OCIS codes: (140.3280) Laser amplifiers; (140.3298) Laser beam combining; (140.3510) Lasers, fiber; (140.3615) Lasers, ytterbium; (290.5830) Scattering, Brillouin

\section{I. 서 론}

지난 수십여 년간 다양한 광학 분야에서 이루어진 눈부신 과학-기술적 발전 성과는 레이저의 발전에서 그 출발점을 찾을 수 있다고 해도 과언이 아니다. 레이저의 출력 수준이 상승하고, 빔 품질이 향상됨에 따라 레이저는 통신, 정밀 측 정, 바이오, 의료에서부터 대형 구조물의 드릴링, 용접, 절단, 또한, 국방에 이르기까지 폭넓은 분야에서 중추적인 기술 요 소로 자리 매김을 하고 있다 ${ }^{[1-8]}$. 레이저 시스템은 다양한 방 식으로 구성될 수 있는데, 최근에는 광섬유를 이득 매질로 하는 광섬유 레이저가 벌크(Bulk) 방식 레이저 시스템과 대 비되는 다양한 장점에 힘입어 많은 연구 및 개발 관심을 받 고 있다 ${ }^{[9-25]}$. 광섬유 레이저는 광신호가 자유 공간이 아닌 실 리카 기반 광섬유 코어를 통해 유도된다는 점에서 시스템 안 정성이 높고, 광에너지 변환 효율이 우수하다. 또한 출력 빔 품질이 뛰어 나고, 이득 대역폭이 넓다는 장점을 가진다. 더 불어 전광섬유 구조로 시스템이 구현 가능하여 광학적 정렬 (Alignment)이 최소화될 수 있으므로, 시스템 구현 및 유지 보수가 매우 용이하다. 이와 같은 탁월한 특성으로 인해 1990년대 후반부터 광섬유 레이저 시스템은 기존의 벌크 방 식 레이저 시스템의 대안으로 학계 및 산업계의 뜨거운 관심 을 받기 시작했고, 세계 유수 연구진들의 활발하고 심도 있 는 연구를 통해 광섬유 레이저 기술은 최근 20 년간 눈부신 속도로 발전해 왔다. 특히 단일 모드 연속광 광섬유 레이저 의 경우, 가용 평균 출력의 범위가 $20 \mathrm{~kW}$ 수준에 이를 만큼 그 비약적인 발전이 계속되고 있다 ${ }^{[11]}$.

그러나, 광섬유 레이저는 전술한 다양한 장점을 갖는 동시 에 극복해야 할 요소들 또한 지니고 있는데, 특히 좁은 코어 영역 내에서 긴 전파 길이에 걸쳐서 광신호가 증폭되는 광섬 유 레이저의 구조는 자가 위상 변조(Self-Phase Modulation), 4파 혼합(Four-Wave Mixing), 유도 브릴루앙 산란(Stimulated Brillouin Scattering: SBS), 유도 라만 산란(Stimulated Raman Scattering: SRS) 등의 비선형 현상이 발생하기 쉬운 조건을 제공한다 ${ }^{[9,12,17,26-39]}$. 이는 광신호의 스펙트럼 확대, 파장 변 이, 후방 산란 등의 원치 않는 현상을 야기해 레이저 시스템 의 안정성 및 에너지 변환 효율을 저해하므로, 결과적으로
광섬유 레이저의 가용 출력을 제한하게 된다. 특히 비선형 현상은 본질적으로 광섬유의 출력이 증가함에 따라 더욱 심 각한 결과를 초래하게 된다는 점에서 현재까지도 이를 억제 하기 위한 다양한 방안들이 모색되고 있는 실정이다. 최근에 는 비선형 현상과 더불어 모드 불안정 현상 또한 광섬유 레 이저의 출력을 제한하는 요소가 될 수 있다고 보고되고 있는 데 ${ }^{[11,40-48]}$, 이는 광신호의 평균 출력에 따라 출력 빔 모드 특 성이 심각하게 왜곡되는 현상으로, 특히 광섬유의 코어가 크 고 그 유효 개구수(Numerical Apeture)가 낮으며 상대적으로 펌프광 흡수율이 높은 막대형 이득 광섬유(Rod-Type Gain Fiber)에서 더욱 현저히 발생한다 ${ }^{[41-47]}$. 이러한 다양한 비선형 현상과 모드 불안정 현상은 광섬유 레이저 출력 수준의 계속 적인 향상을 바라는 관점에서는 반드시 심도 있게 논의되고, 해결되어야 하는 과제들임에 틀림이 없다. 본 논문은 이와 같은 취지에서 지금까지 광섬유 레이저의 성장을 이끈 여러 주요 연구 성과들을 되짚어 보고, 앞으로의 발전 방향을 논 의하고자 한다. 광섬유 레이저는 시스템 구성에 따라 연속광 에서 극초단 펄스에 이르는 다양한 형태의 빔을 발진하거나 증폭할 수 있지만, 본 논문에서는 특별히 고출력 연속광 (Continuous Wave) 레이저 시스템의 경우로 논의를 한정하 는 바이며, 따라서, 본 논문 상의 레이저 출력은 기본적으로 평 균 출력(Average Power)에 해당함을 미리 밝혀 두고자 한다.

본 논문의 구성은 다음과 같다. 제 2 장에서는 최근까지의 광섬유 레이저 출력의 성장 추세를 개괄하고, 이를 뒷받침하 는 기술 동향을 살펴보기로 한다. 제 3 장에서는 이러한 광섬 유 레이저의 출력 증대를 제한하는 다양한 현상적 요인들에 대해 논의하고자 한다. 제 4 장에서는 제 3 장에서 논의된 광섬 유 레이저의 출력 제한 문제에 대한 대안적 해결 방안으로 각광받고 있는, 다수의 광섬유 레이저들로부터 발진되는 개 별 레이저 빔들을 결합하여 단일 레이저 빔을 합성하는, 다 양한 다중 빔 결합 기술들을 논의하고, 특히, 현 기술개발 현 장에서 많은 주목을 받고 있는 분광형 빔 결합(Spectral Beam Combination: $\mathrm{SBC}$ ) 방식의 주요 기술 현안과 연구 쟁점에 대해 좀더 심도있는 논의를 진행한다 ${ }^{[49-57]}$. 최종적으로 제 5 장 에서는 앞으로의 고출력 광섬유 레이저 기술에 대한 전망 및 발전 방향을 제시하며 본 논문의 논의를 마무리하고자 한다. 


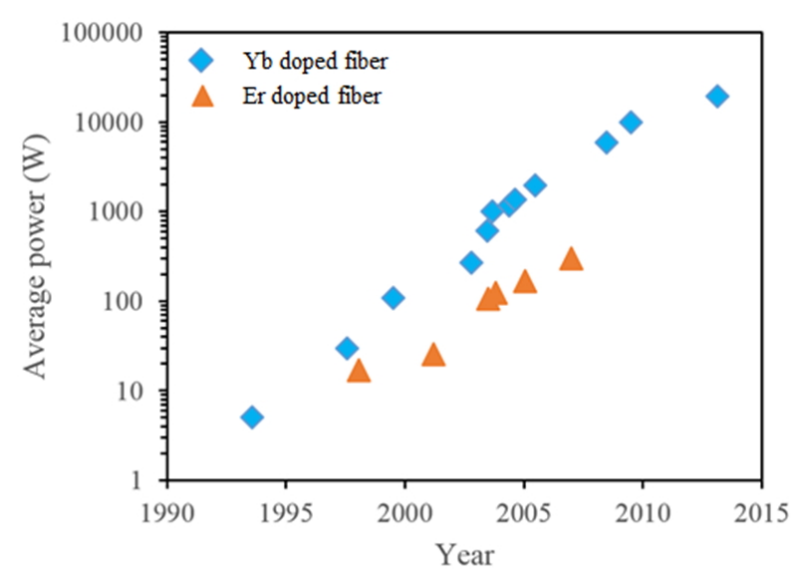

FIG. 1. Evolution of the average output power of fiber lasers.

\section{II. 고출력 광섬유 레이저의 발전 현황}

광섬유 레이저의 출력 수준은 Fig. 1 에서 나타난 바와 같이 최근 20 여 년간 괄목할 만큼의 성장을 거듭해 왔다. 연간 출 력 성장률은 평균적으로 1.7 배에 달하며, 이미 2003년에는 불가능할 것으로 여겨졌던 단일모드 $1 \mathrm{~kW}$ 의 출력 장벽을 넘 어서게 되었고 ${ }^{[14,15]}$, 그 발전을 거듭하여 2009 년 단일모드 10 $\mathrm{kW}$ 급 광섬유 레이저 시스템이 상용화된 바 있으며 ${ }^{[18]}, 2013$ 년에는 단일모드 $20 \mathrm{~kW}$ 급 광섬유 레이저의 성공적인 발진 에 대한 보고가 있다 ${ }^{[11]}$. 이와 같은 급속한 출력 성장에 힘입 어, 광섬유 레이저는 다양한 응용 분야에서 기존의 벌크 방 식 레이저를 대체하거나 새로운 응용을 창출해 내는 성장 동 력 기술로 자리잡기 시작했다. 이와 같은 광섬유 레이저의 고무적인 발전을 가능하게 한 주요 핵심 기술 요소들을 이하 에서 간략히 논의하고자 한다.

일반적으로 고출력 광섬유 레이저 시스템은 Fig. 2에 나타 난 바와 같이 레이저 공진기(Laser Oscillator) 구조 및 주공 진기 출력 증폭기(Master-Oscillator Power Amplifier: MOPA) 구조의 두 가지 방식으로 구현된다. Figure 2(a)의 레이저 공 진기 구조에서는 별도의 외부 입력 신호 광원 없이, 이득 광 섬유에서 발생하는 자연 방출(Spontaneous Emission)과 이득 광섬유 양단에 위치해 거울 역할을 하는 되먹임 소자(통상적 으로 광섬유 격자 소자가 이용됨)에 의해 특정 신호광이 생 성 및 선택되고, 또한, 이 특정 신호광이 반복적으로 공진기 내부에 되먹임되면서 이득 광섬유에서 유도 방출(Stimulated Emission)이 유도되어 최종적으로 공진기 내에서 발진되는 방식이다. 이 때 한 쪽 되먹임 소자는 일정 수준의 투과율을 유지하여 신호광의 일부가 공진기 외부로 출력되도록 한다. 이와 같은 레이저 공진기 구조는 고출력 광섬유 레이저를 구 현하는데 가장 간단하고 효과적인 방식이나, 신호광의 특성 이 주로 이득 광섬유 및 공진기 구조 자체의 특성에 따라 결 정되기 때문에, 협대역 파장 및 극초단 펄스폭 등의 특수한 성질을 갖는 신호광을 고출력으로 직접 생성하는데 있어서 는 그 기술적인 한계가 있다. 이와 비교할 때, Fig. 2(b)의 MOPA

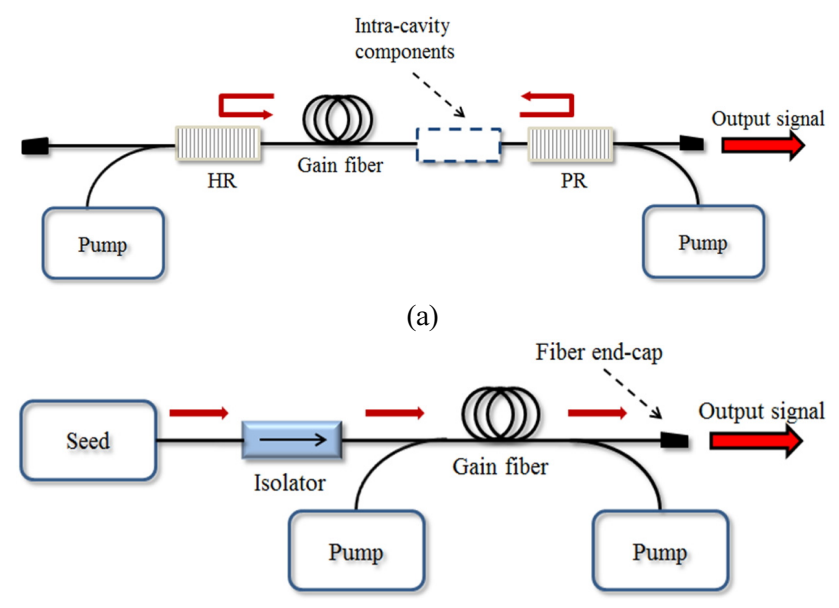

(b)

FIG. 2. Schematics of (a) a resonator-type laser and (b) a MOPA system.

구조에서는 주공진기에서 생성된 저출력 시드(Seed)광이 고 출력 증폭을 담당하는 출력 증폭기와 분리되어 순차적으로 증폭되어 고출력화되는 방식을 취하기 때문에, 적합한 특성 을 갖는 저출력 주공진기의 선택이 가능하다면 그에 따른 임 의의 특성을 갖는 고출력 신호광을 구현하는 데 있어서 더욱 효과적인 방식이다. 그러나, 신호광이 단방향으로 진행해야 하므로, 고출력에서 동작하는 광격리기(Optical Isolator)의 사 용이 요구되고, 또한 증폭 단계에서 발생하는 잡음에 의해 신호광이 왜곡될 가능성이 있어, 이에 대한 적절한 조절과 대응이 요구된다. 이러한 레이저 공진기 구조와 MOPA 구조 를 통해 구현되는 고출력 광섬유 레이저 시스템의 출력 성장 원동력 요소들을 다음에서 보다 상세히 논의해 보고자 한다. 고출력 광섬유 레이저의 이득 매질로 주로 사용되는 이터 붐(Ytterbium: $\mathrm{Yb}$ ) 물질은 매우 우수한 레이저 발진 특성을 가지고 있다. 광통신 파장 영역(1530-1560 nm)에서 이득 매 질로 주로 사용되는 어븀(Erbium: $\mathrm{Er}$ )과 달리 $\mathrm{Yb}$ 은 그 흡수 대역이 900 - $1000 \mathrm{~nm}$ 에 위치하는데, 이는 고출력 고효율의 $\mathrm{InGaAs} / \mathrm{GaAs}$ 기반 레이저 다이오드 (Laser Diode: $\mathrm{LD}$ )의 동 작 대역과 완벽히 겹쳐진다. 따라서, 이러한 고출력 고효율 의 $\mathrm{LD}$ 사용의 용이성은 광섬유 레이저의 펌핑을 구현하는 데 있어서 큰 이점으로 작용할 수 밖에 없는데, 그 동안의 $\mathrm{LD}$ 기반 펌프 광원의 평균 출력과 빔 품질의 향상과 발전은 $\mathrm{Yb}$ 혼입 광섬유 기반 레이저의 출력 성장에 가장 큰 원동력 의 하나가 되었다고 해도 과언이 아니다.

또한, $\mathrm{Yb}$ 의 경우 $1.1 \mu \mathrm{m}$ 파장 대역에서는 통상적으로 준4레벨 레이저(Quasi-Four-Level Laser)로 동작하는데, 특별 히 흡수 파장 대역과 방출 파장 대역의 차이가 상대적으로 매우 작다. 이는 Fig. 3에서 표시된 바와 같이 펌프광의 에너 지에 해당하는 에너지 준위 4 와 에너지 준위 1 의 차이와 신 호광 에너지에 해당하는 에너지 준위 3 과 에너지 준위 2 의 차이가 상대적으로 매우 근접해 있음을 의미한다. 결과적으 로 여기된 전자가 에너지 준위 4 와 에너지 준위 3 사이와 에 


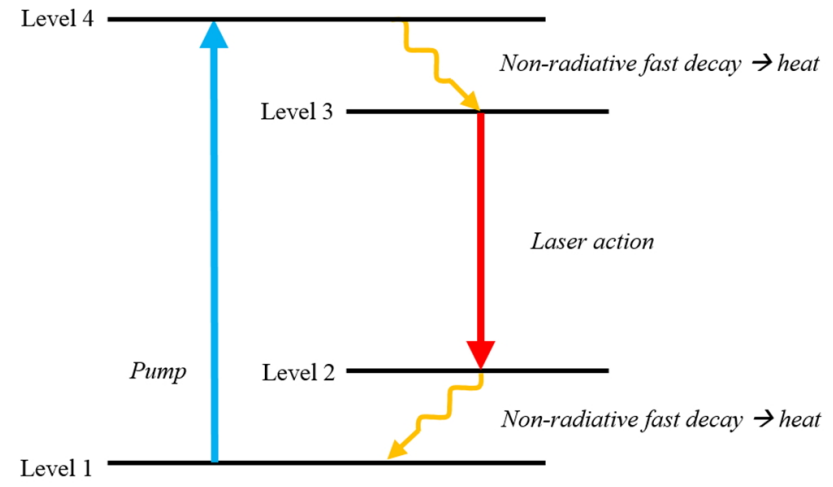

FIG. 3. Energy levels of a four-level laser system.

너지 준위 2 와 에너지 준위 1 사이에서 비광학적 에너지 준위 이동을 하며 겪게 되는 양자 손실이 크지 않아, 결과적으로 증폭 및 레이저 발진 효율이 상대적으로 우수해지게 된다.

$\mathrm{Yb}$ 의 또 다른 장점은 다른 이득 매질과 비교해 고농도 수 준까지 광섬유 매질에 혼입이 가능하다는 점이다. 광섬유에 이득 매질을 고농도로 혼입하게 되면 입자들이 덩어리를 형 성해 원치 않는 에너지 전이가 발생하는 농도소입(Concentration Quenching)현상이 발생하기 쉬운 조건이 되는데, $\mathrm{Yb}$ 의 경우 $\mathrm{Er}$ 보다 농도소입 현상이 발생하는 임계 농도 수준이 횔씬 높 다. 일반적으로 $\mathrm{Yb}$ 은 20,000 ppm(By Weight)을 상회하는 높 은 농도까지도 광섬유 물질에 혼입이 가능하여 ${ }^{[12]}$ 짧은 길이 내에서도 고출력 광을 발진 시킬 수 있을 만큼의 충분한 펌 프 광을 흡수할 수 있어서, 광세기에 의한 광섬유 내 비선형 현상을 억제하는 데 매우 유리하다.

이러한 $\mathrm{Yb}$ 을 비롯한 다양한 이득 물질은 보다 효율적인 고출력 발진을 위해 이중 클래딩 구조의 광섬유의 코어 영역 에만 선택적으로 혼입이 된다. Figure 4는 이중 클래딩 구조 를 갖는 이득 광섬유에서 펌프광과 신호광의 전파 양상을 보 여 주고 있는데, 그림에서 볼 수 있듯이 이중 클래딩 구조 광섬유에서는 기존 광섬유의 코어-클래딩 구조에 더해 내측 클래딩보다 더 낮은 굴절률을 갖는 외측 클래딩이 존재한다. 따라서, 이중 클래딩 구조 광섬유에서는 펌프광이 코어 영역 뿐만 아니라 내측 클래딩 영역으로도 전파될 수 있는 특성을 가진다. 내측 클래딩은 코어보다 면적이 매우 넓고, 외측 클 래딩의 굴절률을 충분히 낮게 조절할 경우 0.4 이상의 높은 개구수 값을 가질 수 있으므로 외부 펌프광에 대한 수용면적 및 수용각이 효과적으로 증대되어, 빔 품질이 상대적으로 매 우 낮은 $\mathrm{LD}$ 기반 고출력 펌프광을 광섬유 내부로 유입하는 데 매우 유리하다. 즉, 가용한 펌프광의 유입량을 대폭 증대 시킬 수 있는 특성을 가지게 된다. 결과적으로 이중 클래딩 구조 광섬유는 2003 년 $1 \mathrm{~kW}$ 출력 달성 사례를 비롯해, 고출 력 광섬유 레이저의 핵심 기술로 자리 잡았다 ${ }^{[9,14-16]}$.

최근에는 고출력 광섬유 레이저의 발진 효율을 한층 더 극 대화 할 수 있는 종렬(Tandem) 펌프 기술이 주목을 받고 있 다. 종렬 펌프 방식은 광섬유 레이저 자체를 펌프 광원으로 사용하는 기술로 Fig. 5는 종렬 펌프 기술이 적용된 MOPA

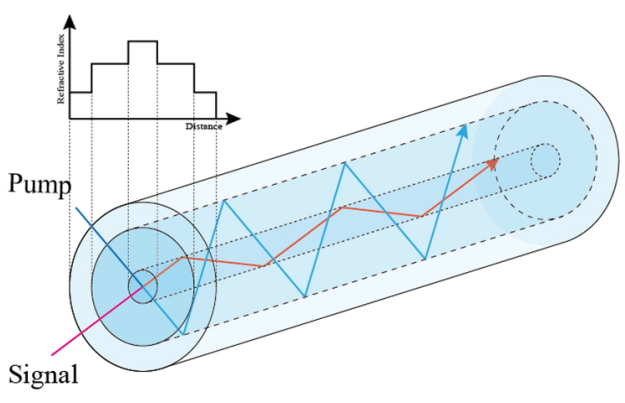

FIG. 4. Geometry of a double-clad fiber.

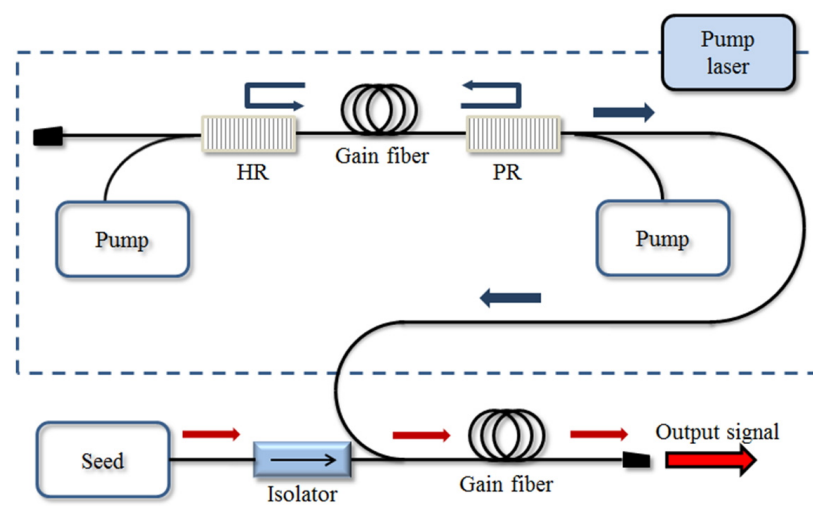

FIG. 5. Schematic of a tandem-pumped MOPA system.

시스템의 한 예를 보여준다.

종렬 펌프 방식은 1 차적으로 $\mathrm{LD}$ 기반 펌프 광원을 이용해 펌프용 광섬유 레이저를 만들고, 이를 통해 최종 광섬유 레 이저를 재차 펌프하는 방식을 취한다. 이 때, 펌프용 광섬유 레이저의 발진 파장은 최종 광섬유 레이저의 이득 매질의 흡 수 파장 대역 내에 위치하도록 하는데, 결과적으로 그 펌프 파장은 일반적인 $\mathrm{LD}$ 펌프 방식일 때의 펌프 파장과 최종 광 섬유 레이저의 신호광 발진 파장의 사이에 위치하게 된다. 다시 말해서 종렬 펌프 방식의 경우 펌프 준위에 해당하는 가상의 에너지 준위4가 신호광이 발진되는 에너지 준위 3 에 더 가깝게 혹은 거의 동일한 에너지 준위 상에 위치하기 때 문에, 종렬 펌프 방식은 밴드 내(In-Band) 펌프 방식으로 불 리기도 한다. 결과적으로 그 양자 결함의 양이 $\mathrm{LD}$ 펌프 방 식 경우에 비해 횔씬 줄어 들게 된다. 다만, 펌프 파장 이동 에 따른 흡수율 저하가 발생할 수 있는데, 1 차 광섬유 레이저 를 통해 발생되는 펌프광의 빔 품질 혹은 빔 밝기(Brightness) 가 통상적인 LD 펌프광의 빔 품질 혹은 빔 밝기보다 월등히 우수하므로, 더 작은 내측 클래딩을 사용하여 펌프광을 코어 근처에서 더 효율적으로 집속할 수 있게 된다. 따라서, 최종 적인 이득 광섬유의 단위길이당 펌프 흡수율 관점에서는 $\mathrm{LD}$ 직접 펌프 방식과 비교할 때와 큰 차이가 없게 된다. 다시 말해서, 이는 더 작은 내측 클래딩 사용을 통해, 그 양자 결 함이 줄어 들 때 발생할 수 있는 파장에 따른 펌프 흡수도 저하를 충분히 보상할 수 있을 만큼의 흡수 효율 향상을 이 끌어 낼 수 있음을 의미한다. 따라서, 동일한 단위길이당 펌 
프 흡수율을 가정할 경우, 양자 결함에 의한 열손실이 $\mathrm{LD}$ 직접 펌핑 방식에 비해 현저히 줄어 들게 되므로, 그 발진 효율은 향상되고, 열 손상에 대한 위험도는 상대적으로 더욱 낮아지게 되는 것이다. 이와 같은 장점들에 기인해 종렬 펌 프 기술은 $10 \mathrm{~kW}$ 급 이상의 광섬유 레이저 시스템의 핵심 요 소로 활용된 바 있고 ${ }^{[11,18]}$, 최근에는 $0.6 \%$ 미만의 양자 결함 을 이용해 발진에 성공한 사례 또한 보고된 바 있다 ${ }^{[24]}$.

\section{III. 광섬유 레이저의 출력 제한 요소}

전술한 바와 같이 광섬유 레이저가 지닌 다양한 장점에 기 인해 활발한 연구 및 기술 개발이 이루어졌고, 그 가용 출력 또한 급속한 성장을 거듭해 왔다. 그러나, 좁은 코어 영역 내 에서 고출력의 레이저 신호광이 전파해 나가는 기본적인 구 조는 다양한 이점을 제공하는 동시에 고출력 동작 영역에서 시스템의 안정성을 저해하는 여러 문제 현상들을 수반하게 한다. 가장 대표적인 현상들로는 광섬유 물질 내 비선형 광 학 현상, 광섬유의 열적 손상, 또는 모드 불안정 현상 등을 들 수 있다. 본 장에서는 앞서 언급된 다양한 광섬유 레이저 의 출력 제한 요소들과 이에 대한 해결 방안을 논의하고자 한다.

\section{1. 비선형 광학 현상에 의한 출력 제한}

비선형 광학 현상은 광신호의 출력에 따라 비선형적으로 발생하는 다양한 광학적 현상을 말하는데, 광섬유 내에서 발 생하는 비선형 광학 현상으로는 크게 비탄성 산란(Inelastic Scattering)에 기반한 현상과 광학적 커 효과(Optical Kerr Effect) 에 기반한 현상들을 들 수 있다. 이하의 내용에서 비탄성 산 란 현상에 해당하는 SBS와 SRS 및 광학적 커 효과에 기반 한 자가 집광(Self Focusing)에 의한 고출력 광섬유 레이저의 출력 제한과 이를 완화하기 위한 방안에 대해 개략적으로 논 의하고자 한다. 특히, 본 논문 후반부에서 다룰 다중 빔 결합 기술의 주요 고려 대상인 SBS에 대해서는 보다 자세한 논의 를 하고자 한다.

$\mathrm{SBS}$ 는 광신호와 음파의 상호작용에 기인한 비선형 현상으 로, 여기서의 음파는 광신호 자체가 브릴루앙 산란(Brillouin Scattering) 현상을 겪으면서 자발적으로 발생시키는 것을 말 한다. 실리카 소재 광섬유인 경우 음파는 대략적으로 $10 \mathrm{GHz}$ 대역의 주파수를 갖게 된다. 이러한 음파는 광섬유의 종방향 으로 전파될 수 있는데, 음파의 소밀 작용과 음향광학 현상 (Acousto-Optic Effect)에 의해 광섬유의 광학적 굴절률이 공 간적으로 변조가 되며, 이 또한 음파의 속도와 동일하게 전 파하게 된다. 그러나, 그 전파 속도가 광신호에 비해 상대적 으로 매우 느리므로, 광신호의 관점에서는 음파에 의해 생성 되어 전파하는 주기적 광굴절률 변조량은 거의 정지상태에 있는 광 브래그 격자처럼 작용을 하게 되어, 주로 광신호로 부터 주파수가 하향천이된 후방 산란광을 야기하게 된다. 다 시 이 후방 산란광은 입력 광신호와 맥놀이(Beating)하여 브 릴루앙 산란 현상을 더욱 유도하게 되는데, 이 경우를 유도
브릴루앙 산란 현상, 즉, SBS 현상이라 한다. 양자 역학적인 관점으로는, 광자와 음향 양자의 충돌로 인한 광자의 산란으 로 설명될 수 있다. 만약, 광자의 결맞음 시간(Coherence Time) 이 브릴루앙 산란에 의해 발생된 음향 양자의 수명시간(Lifetime) 에 비해 상대적으로 현저히 짧지 않다면, 음향 양자에 의해 후방 산란된 광자들의 필드(Field)들이 결맞게 중첩되면서 SBS 현상이 일어날 가능성을 더욱 높이게 된다. 반대로, 광 자의 결맞음 시간이 브릴루앙 산란에 의해 발생된 음향 양자 의 수명시간보다 짧다면, 음향 양자에 의해 후방 산란된 광 자들의 필드가 결맞게 중첩될 확률이 현저하게 낮아지면서 $\mathrm{SBS}$ 현상 또한 미미해지게 된다. 즉, 신호 광원의 광자의 결 맞음 시간을 결정하는 선폭이 음향 양자의 수명시간을 결정 하는 SBS 이득 대역폭보다 상대적으로 좁을 때 SBS 현상이 더욱 효과적으로 발생하는 것이다. 이와 같은 $\mathrm{SBS}$ 의 원리상, 좁은 선폭을 갖는 광신호일수록 후방 산란이 더 잘 일어나게 되는 것이다. 일반적으로 $\mathrm{SBS}$ 현상은 $\mathrm{SBS}$ 임계 출력으로 정 량화 되며, 이는 수식 (1)과 같이 표현된다 ${ }^{[58]}$.

$$
P_{c r}=\frac{C_{0} A_{e f f}}{g_{B} L_{e f f}}
$$

수식 (1)에서 $A_{\text {eff, }} L_{\text {eff, }} g_{B}$ 및 $C_{0}$ 는 각각 광신호의 유효 면 적, 유효 전파 길이, 유효 브릴루앙 이득계수 및 비례상수이 다. $P_{c r}$ 는 $\mathrm{SBS}$ 에 의한 후방 산란광의 출력이 일정 수준에 도 달하기 위해 필요한 입사 광신호의 출력 값을 의미한다. 이 임계값은 신호광원 대비 후방 산란광의 출력이 비선형적으 로 변곡되어 증가하기 시작하는 시점, 신호광원 대비 후방 산란광의 출력이 일정 비율에 도달하는 시점, 혹은 후방 산 란광의 출력이 전체 레이저 시스템에 손상을 가할 수 있는 출력 시점 등 비례상수 $C_{0}$ 값의 적절한 선정을 통해 다양한 방법으로 정의될 수 있는데, 본 논문에서는 후방 산란광의 출력이 $30 \mathrm{~mW}$ 에 도달하는 시점으로 정의한다 ${ }^{[59]}$. 수식에서 볼 수 있듯이 $P_{c r}$ 는 유효 브릴루앙 이득계수 $g_{B}$ 에 반비례하 는데, $g_{B}$ 는 신호광의 선폭과 또한 반비례 관계를 갖는다. 결 과적으로 광신호의 선폭이 좁을수록 SBS 임계 출력 수치가 감소해, 보다 낮은 입력 광신호에서 후방 산란광이 현저하게 발생하게 됨을 의미한다. 따라서, SBS현상은 특별히 협대역 고출력 연속광 광섬유 레이저에서는 반드시 고려 되어야 할 요소에 해당한다.

$\mathrm{SBS}$ 에 대한 면밀한 대처가 없을 경우, 고출력 광신호는 후 방 산란에 의해 큰 출력 손실을 겪을 수 있고, 더불어 고출 력 후방 산란광이 시스템에 회복 불가한 손상을 야기할 수 있다. 따라서 SBS 현상을 억제하기 위한 다양한 연구 방법 이 논의되어 오고 있는데, SBS를 줄일 수 있는 대표적인 방 법 중 하나로, 광섬유의 각 구간별로 온도 혹은 장력에 변화 를 주어 각 구간별로 브릴루앙 천이 주파수를 다양하게 분포 되게 하여, 결과적으로 SBS 이득 대역폭 내에 위치하게 되 는 개별 주파수에 대한 광 이득의 총합을 최소화하는 방법을 사용한다 ${ }^{[28-31]}$. Figure 6 은 이와 같은 방법이 적용된 한 예로, 


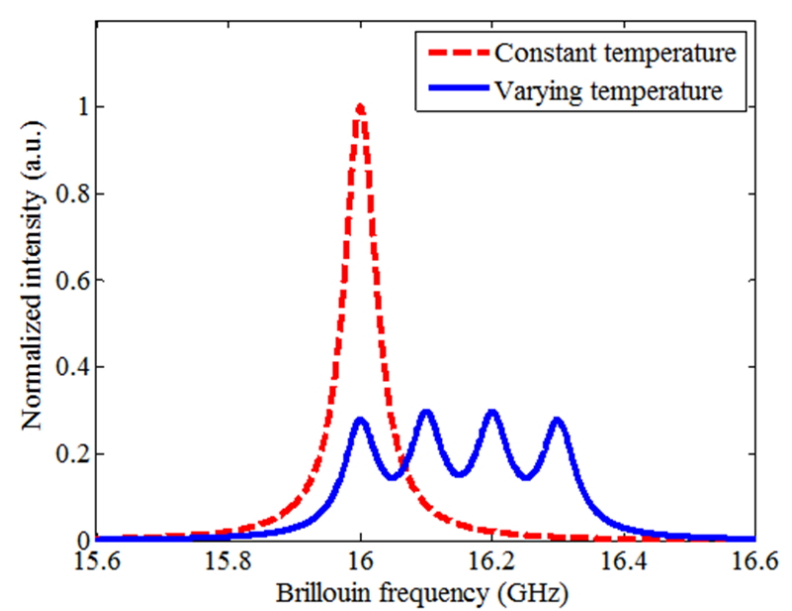

FIG. 6. Spectra of Brillouin-backscattered signal from a 4-m-long fiber with a longintudinally varying temperature distribution (solidblue line) in comparison with a uniform temperature distribution case (dashed-red line).

동일한 양의 SBS가 발생하는 광섬유를 네 구간으로 나누어 $50^{\circ} \mathrm{C}$ 씩 다른 온도를 순차적으로 인가한 경우에 대해 수치적 으로 계산된 브릴루앙 후방 산란광의 스펙트럼을 보여준다. 계산 상에서 온도에 따른 브릴루앙 천이 주파수는 선형적으 로 비례하는 것으로 간주하였다 ${ }^{[30]}$.

Figure 6에서 알 수 있는 바와 같이 온도 변화를 주지 않았 을 경우에는 브릴루앙 후방 산란광 신호 스펙트럼 중심에서 그 광 세기가 집중되는 반면, 각 구간별로 온도를 다르게 인 가하였을 경우에는 후방 산란광이 서로 다른 주파수를 중심 으로 분산되어 생성되었음을 확인할 수 있다. 각 주파수 성 분들은 상호 비결맞음 상태이므로 단일 주파수에 집중된 광 의 세기에 비해, 다수의 주파수로 분산된 광의 세기는 분산 된 주파수의 개수에 비례하여 감소하게 된다.

온도와 더불어 압력 및 장력을 통한 SBS 억제에 관해서도 많은 연구 결과가 보고되어 왔는데 ${ }^{[0,31]}$, 기본적인 원리는 온 도의 경우와 마찬가지로 인가된 압력 및 장력에 비례해 브릴 루앙 천이 주파수가 바뀌는 현상을 이용하는 것이다. 따라서 광섬유를 여러 구간으로 나누어 각 구간별로 압력 및 장력을 다르게 인가해 서로 후방 산란광의 주파수를 공간적으로 분 산시킬 수 있다. 결과적으로 본 방법을 통해서도 다양한 구 성의 광섬유 증폭기 및 레이저에서 SBS 현상을 효과적으로 억제시킬 수 있다. 그러나, 전술된 바와 같이 광섬유 길이에 따라 압력 및 장력을 외부적으로 조절하는 방식은 추가적인 구성 요소를 필요로 하게 되므로 시스템의 복잡성을 증대시 킨다는 단점이 있다.

$\mathrm{SBS}$ 를 줄일 수 있는 또 다른 주요한 방법은, 음파와 광파 의 모드 중첩을 줄여 음파와 광파 간의 상호 작용이 최소화 되도록 설계된 광섬유인, 이른바 음파 역도파 광섬유(Acoustic Anti-Guiding Fiber)를 이용하는 것이다 ${ }^{[32-34]}$. 일반적으로 광 섬유의 코어-클래딩 광 굴절률 형태는 코어 굴절률이 더 높 게 형성된 계단형 분포를 가진다. 이에 반해 음파 역도파 광
섬유의 음파 굴절률(Acoustic Refractive Index)은 반대로, 전 술한 광 굴절률 형태가 역전된, 다시 말해서, 코어 중심에서 굴절률이 가장 낮은 분포를 갖도록 설계된다. 따라서, 음파 의 모드 필드(Mode Field) 분포는 코어의 중심부가 아닌 테 두리 부분에 집중되어 형성되는 반면, 광신호의 경우는 코어 의 중심부에서 그 모드 필드 분포가 집중되어 형성된다. 결 과적으로 음파 역도파 광섬유 구조에서는 광신호와 음파의 공간상 모드 중첩이 최소화되어, SBS 현상 자체도 현저히 줄어 들게 되는 것이다. 온도나 압력 및 장력을 인가하는 방 식과 달리 음파 역도파 광섬유는 시스템의 복잡성을 증대시 키지 않고 SBS를 효과적으로 억제할 수 있다는 장점을 가진 다. 하지만 규격화된 광섬유를 사용하는 것이 아니라. 별도 의 공정 과정을 거쳐 광섬유 자체를 특수 제작해야 한다는 단점이 있다. 더불어 상대적으로 광파와 중첩률이 높은, 음 파의 유출/방사 모드(Leaky/Radiation Mode)로 인해 SBS를 완벽히 억제하는 데 있어서는 한계가 있다 ${ }^{[27]}$.

라만 산란 현상은 광신호가 전파 매질을 구성하는 격자 (Lattice)의 진동과 반응해 산란되는 현상으로, 이러한 라만 산란 현상이 입력 광신호 자체에 의해 현저히 유도되는 경 우, 이를 유도 라만 산란, 즉 SRS 현상이라고 한다. 광신호 는 산란 과정에서 그 광자 에너지의 일부를 잃게 되는데, 이 는 $\mathrm{SBS}$ 의 경우와 마찬가지로 주파수가 일반적으로 하향 천 이되는 현상에 해당된다. SBS와 같이 비선형 산란 현상의 범주에 속하지만, SRS는 $\mathrm{SBS}$ 와 비교할 때 다음과 같은 몇 가지의 현저한 차이점을 갖는다. 먼저, 선폭이 좁을수록 심 하게 발생하는 SBS와 달리, SRS는 광신호의 선폭에 큰 영향 을 받지 않는다. 따라서 신호광의 선폭이 수 $\mathrm{GHz}$ 이하인 협 대역 영역에서는 SBS 현상이 주요한 비선형 산란의 기저 현 상이 되지만, 수십 $\mathrm{GHz}$ 이상의 선폭 영역에서는 그 영향이 미미한 SBS보다는 SRS가 주요한 비선형 산란의 기저 현상 이 되어 광섬유 레이저의 출력을 제한하게 된다 ${ }^{[11]}$. 또한, 주 로 후방 산란광을 야기하는 SBS와 달리 SRS는 전후방 산란 이 모두 현저하게 일어날 수 있으며, 산란광은 실리카 소재 광섬유인 경우 대략적으로 $13.2 \mathrm{THz}$ 의 주파수 하향 천이를 겪는다 ${ }^{[58]} . \mathrm{SBS}$ 에 의한 주파수 하향 천이가 약 $10 \mathrm{GHz}$ 정도 인 것과 비교할 때, 신호광으로부터 천이되는 주파수 차이가 상대적으로 큰 것을 알 수 있다. 즉 $\mathrm{SBS}$ 의 경우와 비교해, 산란광과 신호광의 스펙트럼이 보다 확연하게 떨어져 위치한 다. 이러한 점에 기인해, SRS에 의한 출력 제한의 완화는 주 로 광섬유 레이저 시스템 내부에 주파수 선택 요소 (FrequencySelective Component)를 삽입하는 방식으로 이루어진다. 이 는 다양한 방식으로 구현될 수 있는데, 광섬유에 광 굴절률 이 주기적으로 변하는 격자(Grating) 구조를 설정해 산란광 을 주어진 신호광의 경로에서 이탈시키는 방식이 대표적이 다 ${ }^{[35]}$. 이외에도 특수하게 제작되어 산란광의 파장에서 억제 필터로 작용하는 광섬유를 통해서도 SRS 현상이 효과적으로 완화될 수 있다 ${ }^{[36,37]}$.

앞서 논의한 비선형 산란 현상과 함께, 광섬유의 광 굴절 률이 광신호의 세기에 따라 변하는 광학적 커 효과(Optical 
Kerr Effect)에 기반한 다양한 비선형 현상 또한, 광섬유 레 이저 시스템의 출력이 증대될수록 더욱 현저히 나타나게 되 는데, 그 중에서도 자가 집광(Self-Focusing) 현상이 광섬유 레이저의 출력을 제한하는 대표적인 비선형 현상이다. 광섬 유를 전파하는 광신호의 광세기가 증가할수록 광학적 커 효 과에 의해서 코어 중심부의 광 굴절률이 코어 가장자리부의 광 굴절률보다 상대적으로 더욱 높아지게 된다. 이는 마치 광섬유 자체가 광학적 과집광(Over-Focusing) 볼록 렌즈 역 할을 하게 되어, 이를 통과하는 광신호는 광섬유 중심 부위 로 과집광되는 결과가 초래된다. 자가 집광 현상이 심하게 발생할 경우, 광섬유 코어 중심부로 집광된 고출력의 광신호 는 광섬유에 심각한 손상을 일으킬 수 있다. 자가 집광 현상은 광신호의 평균 출력이 아닌 순간 혹은 첨두 출력(Instantaneous or Peak Power)에 의존하는데, 일반적인 광섬유 실리카 소재 를 사용하는 $~ 1.1 \mu \mathrm{m}$ 에서 동작하는 $\mathrm{Yb}$ 혼입 광섬유 레이저 의 경우 자가 집광 현상에 의한 가용 첨두 출력 임계값은 4 $\mathrm{MW}$ 수준이다 ${ }^{[38]}$. 따라서, 자가 집광 현상은 현재로서는 $\mathrm{kW}$ 급 출력 수준에서 동작하는 연속광 고출력 광섬유 레이저의 경우보다는 주로 펄스형 고출력 광섬유 레이저에서 보다 현 격히 나타나는 현상이라고 하겠다. 자가 집광에 의한 첨두 출력의 한계는 파장의 제곱에 비례하기 때문에 ${ }^{[39]}$, 광섬유 레 이저의 동작 파장을 전환해 그 첨두 출력 한계를 완화시킬 수 있는데, 툴륨 (Thulium)을 이용한 $2 \mu \mathrm{m}$ 광섬유 레이저에 서는 $24 \mathrm{MW}$ 의 첨두 출력 임계값이 보고된 바 있다미.

\section{2. 광섬유 열손상 및 펌프광 흡수 한계에 의한 출력 제한}

$\mathrm{SBS}$ 를 비롯한 비선형 현상과 더불어 광섬유 레이저의 출 력은 광섬유의 열손상, 광섬유 끝단의 광학적 손상, 펌프광 의 흡수 한계 등의 다양한 요인에 의해 제한될 수 있다. 본 절에서는 일반적인 $\mathrm{kW}$ 급 연속광 광섬유 레이저 및 증폭기 시스템에서 발생할 수 있는 주요한 출력 제한 요소들을 살펴 보고자 하며, 보다 일반적인 논의는 참고논문 [26]에서 찾아 볼 수 있다.

이득 광섬유에서 흡수된 펌프광 에너지의 대부분은 바닥 상태의 전자를 여기시켜 신호광의 증폭을 유도하나, 일부분 은 비방사 천이(Nonradiative Transition)에 의해 열로 전환된 다. 일반적인 실리카 광섬유 기반 $\mathrm{Yb}$ 레이저의 경우, 그 효 율이 높은 경우라 할지라도 열로 전환되는 펌프광의 비율은 약 $16 \%$ 에 달한다 ${ }^{[60]}$. 따라서 고출력 광섬유 레이저에서 펌프 광이 흡수되는 코어 영역의 온도는 펌프광량에 따라 꾸준히 상승하며, 이는 열에 의한 광섬유의 균열, 용융 및 열렌즈 현 상 등을 야기한다. 특히 열렌즈 현상은 일반적으로 위 세 가 지 현상 중에서 가장 낮은 임계값을 갖게 되므로 보다 세심 한 관심이 요구된다. 흡수된 펌프광의 비방사 천이를 통해 광섬유 내부에서 열이 발생할 경우, 코어 중심부와 가장자리 부의 온도 차이가 발생하게 되고, 이에 비례하여 코어 영역 의 굴절률 분포가 달라지게 되는 결과가 초래되는데, 이는 전술한 광학적 커 효과에 의한 자가 집광 현상과 유사한 방 식으로 광섬유 내에서 원하지 않는 집광 및 추가적인 온도
상승을 유발하게 된다. 열렌즈 현상에 의해 제한되는 광섬유 레이저의 출력의 임계값은 수식 (2)와 같이 표현된다 ${ }^{[26]}$.

$$
P_{c r}^{\text {lens }}=\frac{\eta_{\text {laser }}}{\eta_{\text {heat }}} \frac{\pi k \lambda^{2}}{2 \frac{d n}{d T} a^{2}} L
$$

여기서 $\eta_{l a s e r}$ 와 $\eta_{h e a t}$ 는 펌프광의 흡수 및 열전환 비율에 해당 하며, $\lambda$ 는 파장, $k$ 는 열전도율을 의미한다. $\mathrm{dn} / \mathrm{dT}$ 은 온도에 의한 굴절률의 변화율이며, $L$ 과 $a$ 는 광섬유의 길이와 코어 반지름에 해당한다. 수식을 통해 알 수 있듯이, 흡수된 펌프 광의 열 전환 비율이 낮을수록, 온도에 의한 굴절률 변화가 작을수록 그 임계 출력이 상승함을 알 수 있는데, 이와 같은 요소들은 광섬유의 물질 특성에 의해 결정되는 값으로 임의 의 요구대로 조절하는 것이 쉽지 않다. 따라서, 일반적으로 광섬유의 코어 직경 및 길이 조절을 통해 그 임계 출력값이 충분히 높아질 수 있도록 설계하게 된다. 주목할 점은, 광섬 유의 직경이 커질수록 비선형 현상 및 후술될 광섬유의 광학 적 손상 측면에서는 고출력 발진에 유리해지나, 열렌즈 현상 측면에서는 반대로 불리해져 그 가용 출력이 감소하게 된다 는 점이다. 이는 광신호의 모드 직경은 코어 직경과 근사적 으로 비례하여 증가하게 되는데, 그 모드 직경이 커질수록 열렌즈 현상으로 형성되는 차등 굴절률 매질(Graded-Index Medium)에서의 집광 정도는 더 심해지는 까닭이다 ${ }^{[26]}$. 따라 서, 열렌즈 현상은 보다 큰 코어 직경을 요구하는 다른 출력 제한 요소들과 동시적으로 고려되어야 하며, 설계되는 광섬 유가 적절한 출력 수준에서 동작할 수 있도록 코어 직경이 결정되어야 할 것이다.

좁은 영역의 코어에서 증폭된 고출력 신호광은 일정 수준 이상의 광세기(Intensity)를 가질 경우 광학적으로 광섬유에 손상을 줄 수 있다. 앞서 논의한 열에 의한 간접적인 손상과 는 달리 이는 광신호 자체에 의한 손상이라는 점에서 차이가 있다. 이와 같은 광학적 손상은 주로 광섬유의 끝단에서 발 생하게 되는데, 주로 광섬유와 공기 경계면에서 굴절률 차이 에 기인해 발생하는 돌발 광학적 손상(Catastrophic Optical Damage), 플라즈마 방사 및 전파로 인한 광섬유 퓨즈 현상 (Fiber Fuse Effect) 등으로 나타난다 ${ }^{[26]}$. 광학적 손상에 의한 광섬유 레이저의 가용 출력 임계값은 수식 (3)과 같이 표현 된다 ${ }^{[26]}$.

$$
P_{c r}^{\text {damage }}=\tau^{2} I_{\text {damage }} \pi a^{2}
$$

여기서 $\tau$ 는 모드 필드 직경(Mode-Field Diameter)의 코어 직 경에 대한 비율이며, $I_{\text {damage }}$ 는 광섬유에 손상이 발생할 수 있 는 광 세기의 임계값에 해당하는데, 일반적인 실리카 광섬유 의 경우 약 $10 \mathrm{~W} / \mathrm{\mu m}^{2}$ 의 값으로 산정한다. 광섬유 끝단의 덧 마감(End-Cap) 처리를 통해 그 임계값을 다소간 상승 시킬 수 있으나, 근본적인 해결책이라고는 볼 수는 없으며, 결국 광섬유 직경과 손상 광세기 임계값을 고려해서 광섬유 레이 
저 시스템을 설계할 필요가 있다.

앞서 논의한 문제 현상들에서 제시된 광섬유 레이저의 출 력 임계값들은 광섬유 레이저 시스템 자체의 안정성과 직결 된 인자들로서, 실제로는 레이저의 동작 안정성 측면에서 앞 서 논의한 임계값 수치들보다 충분히 더 낮은 수준에서 광섬 유 레이저 시스템이 동작되어야 함을 의미한다. 한편, 이와 는 별도로 광섬유에서 유입 혹은 흡수될 수 있는 펌프광량 자체의 한계로 인해 광섬유 레이저의 가용 최대 출력이 제한 되는 경우도 발생한다. 이는 주로 펌프광으로 사용하는 $\mathrm{LD}$ 의 밝기 수준(Brightness) 및 광섬유 코어에 혼입되는 희토류 물질의 농도의 제한성에 기인해 결정되며, 수식 (4)와 같이 표현된다 ${ }^{[26]}$.

$$
P_{c r}^{\text {pump }}=\eta_{\text {laser }} I_{\text {pump }} \pi^{2} N A^{2} \frac{\alpha_{\text {core }} L}{A} a^{2}
$$

여기서 $I_{p u m p}$ 는 펌프광의 광세기로서 클래딩 개구수 값과 더 불어 광섬유 내로 유입될 수 있는 펌프광의 한계값을 결정하 게 된다. $a_{c o r e} L$ 은 펌프광원이 주어진 길이의 광섬유에 흡수 되는 비율을 의미하며 $A$ 는 효과적인 레이저 동작을 위해 설 정된 펌프광의 목표 흡수율을 의미한다. 즉, 펌프 광원의 흡 수율이 목표 흡수율에 근접하지 못할 경우 레이저의 가용 최 대 출력이 제한을 받게 되는 것이다. 펌프 광원에 의해 제한 된 가용 최대 출력을 높이기 위해서는 밝기 수준이 높은 고 성능의 펌프 광원을 사용하거나, 광섬유의 흡수율을 높일 수 있도록 광섬유의 길이, 코어 직경 및 이온 혼입 농도를 조절 할 필요가 있다.

광섬유 레이저의 가용 최대 출력값은 전술한 바와 같이 기 본적으로 여러 복합적인 요소들에 의해 결정되지만, 공통적 으로 광섬유의 코어 직경과 길이에 의존함을 알 수 있다. 따 라서, 고출력 광섬유 레이저 설계 시, 조절이 어려운 다른 변 수에 우선해서 통상적으로 코어의 직경과 길이에 의한 레이 저의 가용 최대 출력값을 분석하는 과정을 거치게 된다. Figure 7은 식 (1) (4) 를 통해 계산된 코어의 직경과 길이에 따른 광섬유 레이저의 가용 최대 출력값에 대한 등고도로, 신호광의 선폭은 후술하게 될 빔 결합 시스템의 광원으로 적 합한 $1 \mathrm{GHz}$ 로 설정되었다. 계산에 사용된 모든 광섬유 파라 미터들은 현시점에서 통상적으로 사용되고 있는 실리카 소
재 $\mathrm{Yb}$ 혼입 광섬유의 특성을 고려해 결정되었으며, Table 1에 정리되었다. 주어진 조건에서 계산된 광섬유의 동작영역은 Fig. 7 에 도시된 바와 같이 $9 \mathrm{~m}$ 의 광섬유 길이, $65 \mu \mathrm{m}$ 의 코 어 직경을 기준으로 세 구역으로 나뉘어지는데, 이는 특별히 광섬유의 최대 출력 제한을 주도하는 현상인 SBS 현상, 열 렌즈 현상, 펌프광 흡수 한계를 기준으로 구분된 것이다. 여 기서 $9 \mathrm{~m}$ 의 광섬유 길이, $65 \mu \mathrm{m}$ 코어 직경은 주어지는 광섬 유 파라미터의 특성에 따라 변동될 수 있는 값들이다. 최종 적으로 특정 지점에서의 가용 최대 출력값은 수식 (1) (4) 에 의해 결정된 4 종의 임계 출력 값들 중 가장 작은 값에 의해 결정된다. 예들 들어, 광섬유의 길이가 $9 \mathrm{~m}$ 이하, 코어의 직 경이 $65 \mu \mathrm{m}$ 이하인 영역에서는 SBS 및 열렌즈 현상에 의한 출력제한은 없으며, 오로지 펌프광 흡수의 한계에 의해서만 광섬유 레이저의 출력이 제한되는 것을 확인할 수 있다. 한 편, 광섬유의 길이가 $9 \mathrm{~m}$ 이상으로 길어진 영역에서는 펌프 광의 흡수량에 의한 제한이 완화되는 반면, SBS 현상이 심 화되어 광섬유 레이저의 출력이 제한된다. 또한, 코어의 직 경이 충분이 커진 경우, 펌프광 흡수 및 $\mathrm{SBS}$ 에 의한 출력 제 한이 완화되어, 열에 의한 집광 현상이 주요 출력 제한 요소 로 대체되는 것을 확인할 수 있다. 결과적으로 이와 같은 분

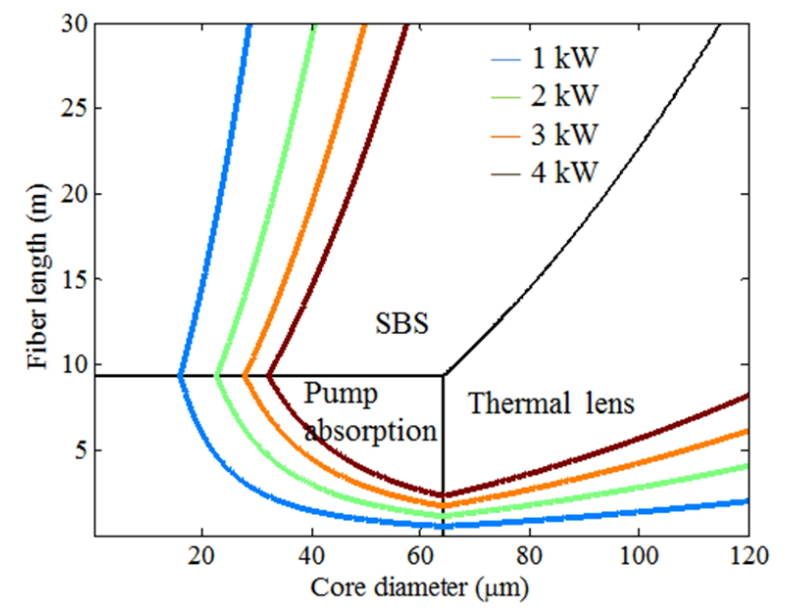

FIG. 7. Contour plot of physical power limits of fiber lasers depending on the fiber length and core diameter. The parameters used in the calculation are presented in Table 1.

TABLE 1. Parameters used in the simulations of Fig. 7

\begin{tabular}{c|c|c|c}
\hline \hline Parameter & Value & Parameter & Value \\
\hline $\mathrm{g}_{\mathrm{B}}(\mathrm{m} / \mathrm{W})$ & $6.79 \times 10^{-13}$ & $\mathrm{dn} / \mathrm{dT}\left(\mathrm{K}^{-1}\right)$ & \multicolumn{1}{c}{} \\
\hline SBS gain bandwidth $(\mathrm{MHz})$ & 60 & $\mathrm{I}_{\text {damage }}\left(\mathrm{W} / \mathrm{m}^{2}\right)$ & 0.8 \\
\hline Signal linewidth $(\mathrm{GHz})$ & 1 & $\mathrm{I}_{\text {pump }}\left(\mathrm{W} / \mathrm{m}^{2}\right)$ & $70^{-5}$ \\
\hline$\eta_{\text {laser }}$ & 0.84 & $\mathrm{NA}$ & $0.45 \times 10^{10}$ \\
\hline$\eta_{\text {heat }}$ & 0.1 & $\alpha_{\text {core }}(\mathrm{dB} / \mathrm{m})$ & 250 \\
\hline $\mathrm{k}(\mathrm{W} / \mathrm{m} \cdot \mathrm{K})$ & 1.38 & $\mathrm{~A}(\mathrm{~dB})$ & 20 \\
\hline$\lambda(\mathrm{nm})$ & 1064 &
\end{tabular}


석을 통해 광섬유의 직경과 길이를 적절히 설계함으로써 레 이저의 가용 출력을 예상할 수 있으며, 또한, 어떤 현상이 우 선적 문제가 되는지 여부를 사전에 분석하여 이에 대한 해결 책을 강구할 수 있다. 예를 들어서, 코어 직경이 $25 \mu \mathrm{m}$ 인 광 섬유를 이용해 $1 \mathrm{~kW}$ 의 출력을 목표로 하는 경우, 위의 분석 을 통해 3 $20 \mathrm{~m}$ 구간에서 광섬유의 길이가 결정되어야 함을 쉽게 알 수 있다. 다른 예로, 광섬유의 직경이 $15 \mu \mathrm{m}$ 일 경우 $\mathrm{SBS}$ 현상과 펌프광의 흡수량에 의한 제한으로 $1 \mathrm{~kW}$ 의 출력 이 주어진 조건에서는 원천적으로 불가능하기 때문에, SBS 의 억제를 위한 추가적인 방안이나 밝기 수준 혹은 휘도 (Brightness) ${ }^{[56]}$ 가 더 높은 펌프 광원을 필요로 하게 됨을 이 미 예측할 수 있게 되는 것이다.

\section{3. 모드 불안정 현상}

모드 불안정 현상은 2011년 처음으로 보고된, 새로운 유형 의 광섬유 레이저 출력 제한 현상으로서, 신호광의 평균 출 력이 특정 임계값 이상으로 높아지면 레이저 빔의 공간 모드 안정성이 극도로 감소하는 현상을 말한다 ${ }^{[1140-48]}$. 결과적으로 출력 빔의 모양이 일그러지고 불규칙적으로 변해, 빔 품질이 크게 저하된다. 특히 광섬유의 코어가 크고 그 유효 개구수 가 낮으며 상대적으로 펌프광 흡수율이 높은 막대형 이득 광 섬유(Rod-Type Gain Fiber)에서 주로 발생하는 것으로 알려 져 있다 ${ }^{[41-47]}$. 최근 활발한 연구를 통해 이러한 모드 불안정 현상을 설명하고자 하는 여러 배경 이론들이 논의되고 있는 데, 기본 모드와 고차 모드간의 간섭 패턴이 열에 의한 격자 구조를 생성하고, 이를 통해 기본 모드와 고차 모드간의 에 너지 전환이 야기되는 것을 그 기저 현상으로 보는 입장도 그 중의 하나이다 ${ }^{[40,41]}$. 또한, 모드 불안정 현상을 억제하기 위한 다양한 방법들도 최근 활발히 논의되고 있는데, 펌프광 의 파장을 신호광에 근접하게 해 양자 결함을 줄이는 방법, 혼입되는 희토류 물질을 코어 중심에 밀집되도록 분포시키는 방법 등이 제시되었고, 이를 통해 모드 불안정 출력 임계값을 수 배 증가시킬 수 있음이 보고 된 바 있다 ${ }^{[55-48]}$. 향후 모드 불안정 현상에 대한 보다 심도 있는 이론적 논의와 더불어 더욱 효율적인 해결 방안이 제시될 것으로 기대하는 바이다.

\section{IV. 다중 빔 결합 기술의 현황}

전술한 바와 같이 비선형 현상, 열적 손상 및 모드 불안정 현상 등에 의해 단일 광섬유 레이저의 출력이 무한정 증대될 수 없음은 자명하다. 따라서, 이러한 출력 증대의 한계성을 극복하기 위한 방안 중 하나로 이른바 다중 빔 결합 기술이 각광받고 있다 ${ }^{[49,50]}$. 다중 빔 결합 기술은 다수의 광섬유 레 이저 빔을 공간 빔 품질(Spatial Beam Quality) 특성이 열화 됨이 없거나 혹은 최소화되는 조건하에서 단일빔으로 결합 하는 기술로, 각 채널 레이저는 비선형 현상, 열적 손상 및 모드 불안정 현상에 지장 받지 않는, 보다 안정된 출력 수준 에서 동작하게 하며, 채널의 개수에 비례해 최종 출력을 안 정적으로 증가시키는 방법을 말한다. 이 때, 단순한 산술적
인 출력 증대만이 이루어지는 것이 아니라, 결합된 빔은 단 일빔 수준의 빔 품질 특성을 가지게 되어, 결과적으로 레이 저 빔의 휘도가 결합되는 채널 수에 비례하여 증대되는 것이 다. 통상적으로 다중 빔 결합 방식은 같은 파장의 광원들 상 호간의 위상을 일치시켜 결합하는 결맞음형 빔 결합(Coherent Beam Combination: $\mathrm{CBC}$ ) 방식, 상호간의 위상을 고려하지 않는 결합 방법인 비 결맞음형 빔 결합(Incoherent Beam Combination: IBC) 방식으로 구분될 수 있다. $\mathrm{CBC}$ 방식은 다수 채널빔들의 위상 일치가 이상적으로 구현될 경우, 빔 품질의 저하가 없어 높은 휘도의 결합 빔 출력이 가능하다. [여기서 휘도라함은 단위 입체각(Solid Angle)과 단위 면적당 발산되는 빔의 총 출력 광세기로 정의되며 ${ }^{[5]}$, 단일 파장 회 절 임계 빔(Diffraction-Limited Beam)의 경우, 휘도는 $B=$ $P / \lambda^{2}$ 의 수식으로 표현된다. 여기서 $P$ 는 총 출력 광세기, $\lambda$ 는 출력 빔의 중심 파장이다.] IBC 방식에는 대표적으로 평행 빔 결합(Side-By-Side Beam Combination) 방식과 서로 다른 파장의 광원을 중첩시켜서 결합하는 분광형 빔 결합(Spectral Beam Combination: SBC) 방식 등이 있다. 평행 빔 결합 기 술은 상호 결맞음성이 없는 다수의 채널빔을 각 빔 별로 평 행하게 배열하여 빔을 결합하는 기술인데, 이 경우, 결합된 빔의 빔 발산(Beam Divergence)에는 큰 변화가 유도되지 않 지만, 결합된 빔의 직경은 채널 개수에 비례하여 증가하기 때문에, 총 출력 광세기가 증가한다 할지라도 결합된 빔의 휘도는 채널 수의 증가와 함께 향상되지 않고, 단일 채널 빔 과 비슷한 수준에 머무를 수 밖에 없다 ${ }^{[49,50]}$. 반면, 분광형 빔 결합 방식, 즉, $\mathrm{SBC}$ 방식은 각 채널 빔들의 파장을 다르게 한 후, 파장 의존형 분광 소자를 이용하여 각 빔들을 중첩하 여 결합하는 방식을 취하게 되므로, 최종적으로 결합된 빔의 빔 발산 및 직경이 단일빔의 수준으로 유지됨과 동시에, 총 출력 광세기가 채널 수에 비례하여 증가되므로, $\mathrm{CBC}$ 수준의 빔 휘도 향상을 기대할 수 있다. 따라서, 전술한 평행 빔 결 합 방식과 비교해 빔 품질이 우수하고 높은 휘도를 갖는 고 출력 광의 결합이 가능해 $\mathrm{IBC}$ 의 대표적인 기술로 각광받고 있다 ${ }^{[50]}$. 그러나, 서로 다른 파장의 채널빔들을 단일빔으로 결합하기 위해서 파장 의존형 분광 소자를 활용하는 기본 원 리 상, 최종적으로 결합된 빔에는 각 채널 빔의 선폭 및 분 포된 채널 빔들의 전체 파장 대역폭에 비례해 발생하는 각분 산(Angular Dispersion)의 영향이 포함되므로, 최종적으로 이 로 인한 빔 품질 저하가 다소 발생할 수 있다 ${ }^{[53]}$. 따라서 $\mathrm{CBC}$ 방식과 비교할 때 결합된 빔의 휘도가 상대적으로 낮 아 질 수 있는 측면이 있다. 그러나, $\mathrm{SBC}$ 방식은 $\mathrm{CBC}$ 방식 에 비해서 상대적으로 구현이 용이하고, 각 채널빔의 파장 혹은 주파수 선폭을 충분히 좁게 하고, 결합되는 채널 수를 적절히 제한할 경우, 이상적인 $\mathrm{CBC}$ 방식에 근접한 결합 효 율 및 빔 품질을 구현할 수 있다 ${ }^{[49,50]}$. 따라서, 이를 위한 다 양한 방식의 고출력 협대역 광원 시스템에 대한 많은 연구개 발 노력들이 이어지고 있고 ${ }^{[17]}$, 수 $\mathrm{GHz}$ 선폭을 가지면서도 $\mathrm{kW}$ 급 출력을 갖는 MOPA 기반 협대역 광원이 빔 결합 시스 템의 주요 단위 레이저 구성 요소로 적용되고 있다 ${ }^{[59,61]}$. 최 
근 결합 효율의 최적화를 통해 $77 \%$ 에 달하는 휘도 효율 (결 합 빔의 휘도/채널빔의 휘도의 합)이 보고된 바 있으며 ${ }^{[56]}$, 출 력 관점에서는 $\mathrm{SBC}$ 기술을 통해 $30 \mathrm{~kW}$ 에 이르는 출력의 연 속광 발진 사례가 보고된 바 있다 ${ }^{[62]}$. 더욱이 국내에서도 $\mathrm{SBC}$ 방식을 활용한 고출력 레이저 시스템 개발 및 응용에 대한 관심이 고조되고 있는 시점에 있기 때문에, 본 논문은 $\mathrm{SBC}$ 기술에 좀 더 높은 비중을 두고 다중 빔 결합 기술의 구성 방식 및 핵심 요소를 다음과 같이 논의하고자 한다.

\section{1. 결맞음형 다중 빔 결합 기술}

$\mathrm{CBC}$ 방식은 다수의 레이저 빔들이 상대적으로 동일한 위 상, 주파수 및 편광 상태를 갖도록 각각의 레이저 빔을 되먹 임 제어하여 최종적으로 하나의 빔으로 결합하는 기술이다. 단일 광섬유 레이저 시스템으로는 앞서 언급한 바와 같이 비 선형 효과 및 광섬유의 손상 가능성으로 인해 가용한 출력에 한계가 존재하는 반면, $\mathrm{CBC}$ 는 구현이 완벽할 경우 스펙트럼 및 빔 품질을 동일하게 유지하며 채널 수의 제곱에 비례해 광세기 밀도(Intensity)를 증대시킬 수 있어 학계의 많은 관심 을 이끌었다 ${ }^{[49-52]}$. $\mathrm{CBC}$ 의 구현에 가장 핵심적인 요소는 각 채널 레이저빔의 위상을 일치시키는 것으로, 위상 잠금 구현 방식에 따라 크게 능동형 위상 잠금 방식(Active Phase-Locking) 과 수동형 위상 잠금 방식(Passive Phase-Locking)으로 분류 될 수 있다 ${ }^{[49,50]}$

Figure 8(a)는 일반적인 능동형 위상 잠금 방식의 $\mathrm{CBC}$ 시 스템 구성을 나타낸다. 초기 시드광은 단일 광원으로부터 생 성되며, 여러 개의 광 채널로 나뉘어져 각 채널별 증폭단으 로 유입된다. 이후 채널별로 증폭 단계를 거쳐 결합기를 통 해 단일빔으로 재구성된다. 이 때 각 채널별 증폭단의 광경 로 차이에 의해 각 채널별 빔 사이에 상대적인 위상 차이가 발생하게 되는데, 이를 보정하기 위해서 결합 과정을 거친 후 재구성된 출력 빔의 위상 정보를 측정하고, 이를 통해 각 채널별 입력 위상을 실시간으로 변조하여 되먹임(Feedback) 제어한다. 이러한 일련의 과정을 통해 최종적으로 결합된 각 채널별 출력 빔에는 위상차가 최소화되도록 하는데, 위상 차 이를 최소화하는 본 과정이 능동형 $\mathrm{CBC}$ 시스템 기술의 핵 심이라 하겠다. 능동형 $\mathrm{CBC}$ 시스템은 되먹임 신호 처리 알 고리즘의 발전에 따라 점차 그 결합 효율이 향상 되고 있는 데, 최근 이른바 LOCSET(Locking of Optical Coherence via Single-Detector Electronic-Frequency Tagging) 방식의 $\mathrm{CBC}$ 시스템에서 $80 \%$ 의 효율로 결합된 $2.4 \mathrm{~kW}$ 의 빔 출력이 보고 된 바 있다 ${ }^{[52]}$. 하지만 다채널 위상에 대한 동시적 제어는 여 전히 더욱 개선될 여지가 있으며, 향후 점진적으로 더욱 향 상된 효율의 $\mathrm{CBC}$ 시스템이 구현 가능할 것으로 기대된다.

Figure 8(b)는 일반적인 수동형 위상 잠금 방식의 $\mathrm{CBC}$ 시 스템 구성을 나타낸다. 수동형 잠금 방식에서는 앞서 논의한 능동형 잠금 방식에서와는 달리 추가적인 능동형 되먹임 요 소가 없으며, 그 대신 단방향 증폭기가 아닌 공진기 형태로 그 시스템이 구성된다. 그림에서 볼 수 있듯이 각 채널별로 증폭단은 분리되어 있지만, 최종단의 출력은 상호 공유된 단

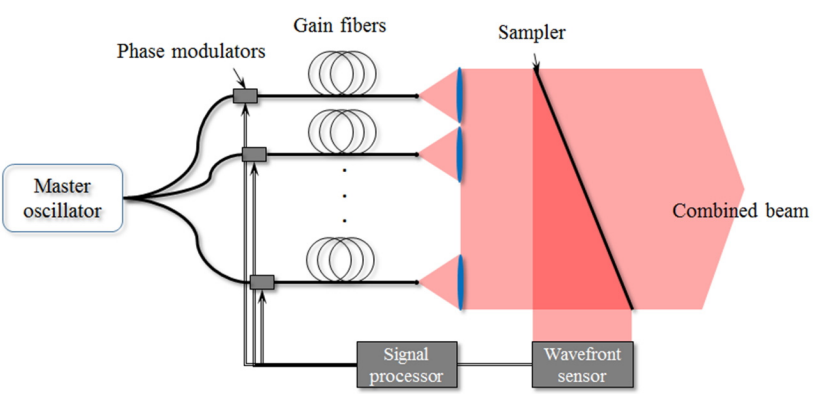

(a)

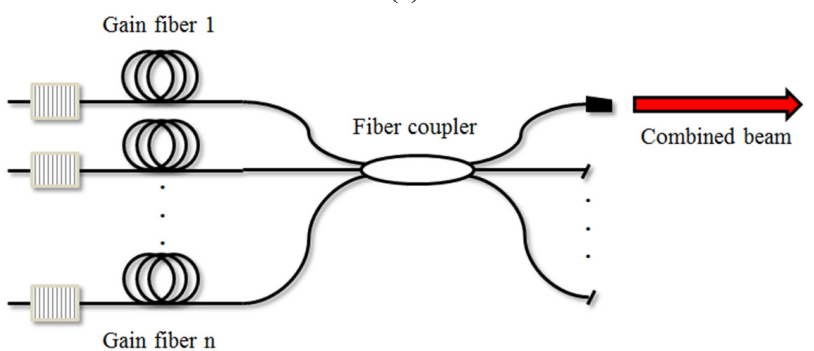

(b)

FIG. 8. Schematic of (a) active and (b) passive CBC systems.

일 출력 결합기를 사용하는 방식이다. 다시 말해서, 각 채널 별 증폭단의 광경로 차이에 의한 위상 차이가 존재하더라도, 출력 결합기와 공진기의 공유를 통해 주입 잠금(Injection Locking)을 유도하게 되어, 각 채널별로 발진되는 레이저 빔 의 주파수와 위상이 자발적으로 일치될 수 있다. 이때 출력 결합기는 각 채널빔들간의 상호 결합(Coupling)을 유도해 동 일한 위상을 공유하는 중첩모드(Super-Mode)를 형성하게 한 다 ${ }^{[49]}$. 수동형 위상 잠금 $\mathrm{CBC}$ 방식은 능동형 위상 잠금 $\mathrm{CBC}$ 방식에 비해 장치의 복잡성이 상대적으로 낮다는 장점이 있 지만, 채널의 수가 많아질수록 그 결합 효율이 저하되는 단 점이 지적된다. 향후 보다 심도 있는 연구를 통해 자발적인 주파수 및 위상 일치 현상에 대한 물리적, 수학적 원리의 확 립과 더불어 각 증폭단의 길이, 연결 계수 등의 핵심적인 변 수들의 보다 광범위한 최적화 과정에 대한 후속 연구가 더 필요할 것으로 기대된다.

\section{2. 분광형 다중 빔 결합 기술}

$\mathrm{SBC}$ 방식은 $\mathrm{CBC}$ 와 대조적으로 상호 결맞음성이 없는 (Incoherent) 채널빔들을 단일빔으로 결합하는 방식이다. CBC 기술과 비교할 때, 각 채널빔들의 개별 위상들에 대한 제어 가 필요 없고, 편광에 대해서도 크게 민감하지 않기 때문에, 결과적으로 시스템이 간편하고 구현하기에 용이하다는 장점 을 갖는다 ${ }^{[49]}$. 또한 $\mathrm{CBC}$ 와는 달리 $\mathrm{SBC}$ 방식에서는 각 채널 별 레이저들의 동작 파장을 일정 간격으로 분산시키고, 각 채널별로 분리된 증폭 과정을 거친 후, 파장 의존 광 경로 변화를 유도할 수 있는 체적 브래그 격자(Volume Bragg Grating) 나 회절 격자(Diffraction Grating)를 빔 결합기로 이용해 최 종적으로 다수의 증폭된 개별 빔들을 단일빔으로 결합하는 방식을 택한다. 
Figure 9는 SBC 시스템의 개념도로 SBC 구현에 필요한 핵심적인 요소들을 나타낸다. Figure 9(a)는 MOPA 방식의 $\mathrm{SBC}$ 시스템을 보여 주며, 크게 시드 레이저, 채널별 증폭기, 결합기로 구성되어 있다. 시드 레이저는 증폭 단계의 입력 신호에 해당하는 시드광을 채널별로 생성하는 단계이다. 일 반적으로 시드광들의 파장은 결합기의 파장 특성을 고려해, 채널별 증폭기의 증폭 밴드폭 내에 위치되도록 결정된다. 각 채널별 시드광의 선폭은 최종적으로 생성되는 결합 빔의 품 질과 $\mathrm{SBS}$ 발생 간의 조정과 절충을 고려해 결정되는데, 일 반적으로 수 $\mathrm{GHz}$ 수준에서 결정된다. 채널별 시드광들은 개 별 증폭단에서 수백 $\mathrm{W}$ 내지 수 $\mathrm{kW}$ 출력 수준까지 증폭된 다. 희토류가 혼입된 광섬유 증폭기는 우수한 빔 품질과 다 수의 채널로 구성되는 빔 경로를 보다 조밀하게 배치할 수 있는 장점을 지녀, $\mathrm{SBC}$ 시스템의 증폭 단계에 매우 적합하 다. 본 증폭 단계에서는 $\mathrm{SBS}$ 를 비롯한 비선형 현상이 현저 히 발생할 수 있으므로 이를 충분히 고려해 최종 증폭단이 설계될 필요가 있다.

채널별로 증폭된 고출력 채널빔들은 최종적으로 빔 결합기 를 통해 공간상에서 동일한 빔 위치와 진행 방향을 갖도록 결합된다. 이와 같은 역할을 수행하기 위해 빔 결합기는 서 로 다른 파장을 가진 빔에 대해서 적절한 회절 특성을 가져 야 하는데, 이는 투과형 또는 반사형 회절 소자로 구현될 수 있다. 광손실이 적고, 다수의 채널에 대해서도 시스템 구성 이 용이한 체적형 브래그 격자, 반사형 회절 격자 등이 대표 적으로 사용되고 있는 고출력 빔 결합기의 예라고 할 수 있 다 ${ }^{[53-56]}$. 파장에 따라 투과 및 반사 각도가 달라지는 빔 결합 기의 고유 특성을 통해 서로 다른 입사각을 갖는 각 채널빔 들을 단일빔으로 결합시킬 수 있는데, 이 때 빔 결합기에 대 한 각 채널빔의 입사각은 시드 레이저에서 설정된 파장에 따 라 정교하게 정렬되어야 한다 ${ }^{[57]}$.

Figure 9(b)는 링 공진기 방식의 SBC 시스템을 나타낸다. 앞서 9(a)에서 논의된 MOPA 방식 시스템과는 달리, 출력 결 합 빔의 일부가 재차 증폭단으로 순환 주입되어 시드광 역할 을 다시 하게 되는데, 이는 시드광의 파장 특성에 관한 자동 적인 되먹임으로 작용해 시스템의 안정성을 높여 주게 되어 서, 장시간 걸쳐서도 안정적으로 동작할 수 있게 된다. 반면, $\mathrm{MOPA}$ 방식의 $\mathrm{SBC}$ 시스템의 경우는 만약, 별도의 파장 안 정 되먹임 요소가 없다면 각 채널빔들의 파장 위치 요동에 대한 즉각적인 보정이 어려워지게 되는데, 이 경우, 곧 출력 광의 빔 품질 저하가 야기될 가능성이 높아진다. 그러나, 적 절한 파장 안정화 기술이 추가적으로 적용될 경우, 결합되는 빔들의 절대적인 파장 및 파장 간격 등이 임의로 선택 및 조 정 될 수 있게 되므로, 이는 오히려 시스템의 확장성 측면에 서 큰 이점으로 활용될 수 있다.

전술한 바와 같이, $\mathrm{SBC}$ 방식은 $\mathrm{CBC}$ 방식과 비교할 때, 상 대적으로 시스템 구현이 용이하고 지속적인 위상 보정 과정 을 거치지 않아도 되는 장점을 갖지만, 여전히 실제 시스템 구현 시 고려해야 할 여러 기술적 어려움들이 존재함은 주지 된 사실이다. 다음 절에서는 $\mathrm{MOPA}$ 방식의 $\mathrm{SBC}$ 시스템에서

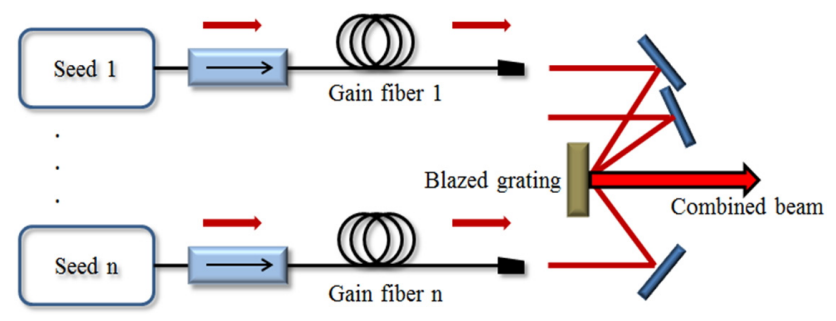

(a)

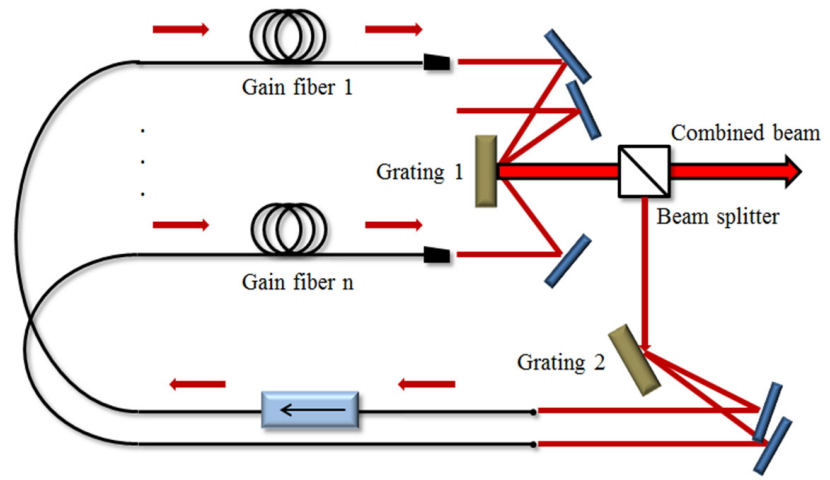

(b)

FIG. 9. Schematic of SBC systems based on (a) a MOPA configuration and (b) a ring cavity configuration.

요구되는 주요 설계 요소들을 보다 상세히 논의하고자 한다.

\subsection{1. $\mathrm{SBC}$ 를 위한 시드 광원 구성}

증폭단 이전 저출력 신호를 제공하는 시드 광원은 $\mathrm{LD}$, 광 섬유 레이저 등을 포함하는 다양한 방식의 협대역 레이저 소 자로 구성될 수 있는데, 시스템의 소형, 경량화 및 안정성 관 점에서 본다면 협대역으로 동작하는 $\mathrm{LD}$ 를 우선적으로 시드 광원으로 선택할 수 있다. $\mathrm{LD}$ 를 통해 생성되는 시드 광신호 의 선폭은 일반적으로 수십 $\mathrm{GHz}$ 이상의 수준 또는 수 $\mathrm{MHz}$ 이하의 단일 종모드 수준의 두 유형으로 구분될 수 있는데 ${ }^{[63]}$, 전자의 경우 결합 빔 품질이 선폭이 넓어질수록 저하된 다는 점에서, 또한, 파장 간격이 과도하게 넓어지게 되면 결 합 가능한 최대 채널 수가 결국 줄어들게 되기 때문에, 시스 템 확장성 측면에서 $\mathrm{SBC}$ 방식의 이점들을 충분히 살리지 못 하게 된다. 한편 후자의 경우, 시드 광의 선폭이 일반적인 실 리카 소재 광섬유의 브릴루앙 이득 대역(약 $60 \mathrm{MHz})$ 보다 ${ }^{[30]}$ 현저히 좁으므로, 만약 $\mathrm{kW}$ 의 출력 수준으로 증폭된다고 가 정한다면, 필연적으로 전술한 바 있는 $\mathrm{SBS}$ 현상을 심각하게 야기하게 되는데, 이를 해결하기 위해서는 시드 신호의 선폭 을 일정 수준으로 증대시킬 필요가 있다. 통상적으로 브릴루 앙 이득의 대역폭인 수십 $\mathrm{MHz}$ 수준보다 충분히 크고, 최종 결합 빔 품질의 저하가 심각하지 않은 $\mathrm{GHz}$ 수준에서 시드 광의 선폭을 결정한다 ${ }^{[59]}$. 시드 광의 선폭 증대는 Fig. 10에 나타난 바와 같은 위상 변조 기술을 통해 구현될 수 있다.

위상 변조 기술은 입력 신호의 위상을 변조해 신호의 스펙 트럼 대역폭을 증대시키는 기술로, 입력 신호의 에너지 손실 이 적고, 광전자적으로 구현이 용이하다는 장점을 가진다. 


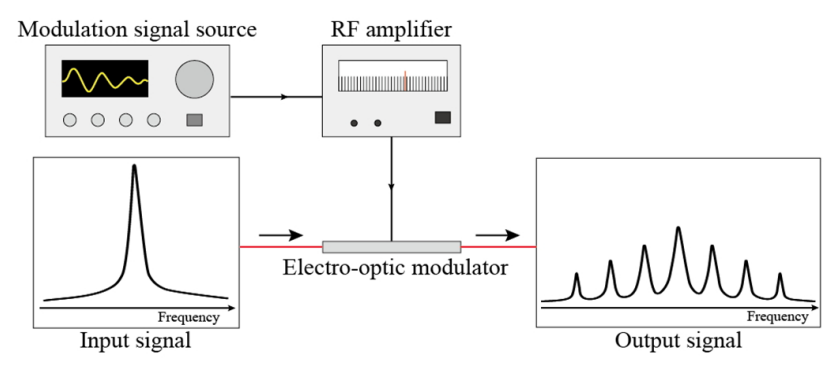

FIG. 10. Schematic of a phase modulation system.

Figure 10에서 볼 수 있듯이, 변조 신호는 무선 주파수 증폭 기(Radio-Frequency Amplifier)에서 증폭된 후 전광 변조기 (Electro-Optic Modulator)를 통해 입력 광신호의 위상에 인 가된다. 전기적 변조 신호에 의한 입력 광신호의 위상 변화 는 수식 (5)로 표현된다.

$$
E_{\text {out }}=E_{0} \cos \left(\omega t+\pi \frac{V(t)}{V_{\pi}}\right)
$$

여기서 $E_{o u t}$ 은 변조 이후의 광신호, $E_{0}$ 는 입력 광신호의 진폭, $V(t)$ 는 전기적 변조 신호에 해당한다. 수식에서 알 수 있는 바와 같이 인가되는 전기적 변조 신호에 의존해 입력 광신호 의 위상이 변조되고, 결과적으로 입력 광신호에 추가적인 주 파수 성분이 생성된다. 변조 신호의 특성에 따라 최종 광신 호의 스펙트럼 특성과, 또한, 이로 인한 SBS 억제의 효과가 달라지기 때문에, 보다 효과적인 SBS 억제를 위해서는 전기 신호 변조 방식의 선택 및 그 최적화 과정이 매우 중요한 기 술적 쟁점이 된다. 광신호의 파장 대역폭 증대를 위해 주로 사용되는 변조 신호 방식에는 노이즈 신호 방식, 모조 랜덤 이진수 시퀀스(Pseudo Random Binary Sequence) 신호 방식 등이 있다 ${ }^{[59,64,65]}$. 전자는 일반적인 백색 노이즈 광원(White Noise Source)을 인가하는 방식으로, 구현이 가장 용이하다 는 장점을 가지지만 ${ }^{[59,64]}$, 시드 신호의 선폭을 임의로 조정하 기 어려운 단점이 있다. 반면에 후자는 모조 랜덤 이진수 시 퀀스에 따른 디지털 신호를 인가하는 방식으로, 확장된 시드 신호의 스펙트럼이 안정적이고 경우에 따라 실시간으로 조정 가능하다는 장점을 가지는 반면 전자에 비해 상대적으로 구현 이 복잡하고, SBS 억제 효과가 다소 감소되는 단점을 갖는다 ${ }^{[65]}$. 최근에는 임의 함수 생성기(Arbitrary Function Generator) 를 이용해 최적화 알고리즘을 거쳐 시드 신호의 스펙트럼을 최대한 균등하게 다수의 스펙트럼으로 분배하는 방식이 제 안된 바 있는데 ${ }^{[6]}$, 이는 임의 함수 생성기의 성능에 크게 의 존한다는 제약성을 가지나, SBS 억제 효과가 극대화될 수 있어서 최근 많은 주목을 받고 있다. 다양한 방법적 시도와 추가적인 최적화 과정을 통해 SBS 억제 기술과 관련한 향후 기술 개선이 더욱 기대된다.

\subsection{2. $\mathrm{SBC}$ 를 위한 증폭단 구성}

증폭단은 전술한 바와 같이 우수한 빔 품질 및 다수의 채
널광을 조밀하게 배치할 수 있다는 점에서 희토류 혼입 광섬 유로 구성될 수 있다. 그러나, 시드 단계에서 위상 변조를 통 해 선폭 증대된 수 $\mathrm{GHz}$ 선폭의 신호에서도 여전히 고출력 증폭 시, 경우에 따라 최종 증폭단에서 현저한 $\mathrm{SBS}$ 현상이 발생할 가능성이 존재한다. 따라서, 광섬유 증폭기 내에서 $\mathrm{SBS}$ 에 의한 후방산란광의 세기를 분석해, 증폭단의 가용 최 대 출력값 및 길이 등 다수의 증폭단 설계 인자들을 적절히 결정하는 절차가 선행되어야 하는데, 이는 수치해석적 접근 을 통해서도 효과적으로 수행될 수 있다. 선폭을 고려할 때, 시드광은 연속광 또는 준연속광인 것으로 가정할 수 있다. 만약, 시드광의 출력을 $P_{s}$, 펌프광의 출력을 $P_{p}, \mathrm{SBS}$ 에 의한 후방 산란광의 출력을 $P_{B}$ 라고 가정한다면, 광섬유 내 전파 길이 $z$ 에 대해 아래와 같은 연립 미분방정식을 통해 각각의 출력들의 변량들을 표현할 수 있다 ${ }^{[28,30]}$.

$$
\begin{aligned}
& \frac{\mathrm{d} P_{p}}{\mathrm{dz}}=\left(N_{2} \sigma_{e p}-N_{1} \sigma_{a p}\right) \tau_{p} P_{p}-\alpha_{p} P_{p} \\
& \frac{\mathrm{d} P_{S}}{\mathrm{dz}}=\left(N_{2} \sigma_{e s}-N_{1} \sigma_{a s}\right) \tau_{S} P_{S}-\alpha_{S} P_{S}-g_{B} P_{B} P_{S} \\
& \frac{\mathrm{d} P_{B}}{\mathrm{~d} \mathrm{z}}=-\left(N_{2} \sigma_{e s}-N_{1} \sigma_{a s}\right) \tau_{S} P_{B}-\alpha_{S} P_{B}-g_{B} P_{S} P_{B} .
\end{aligned}
$$

위 수식에서 $N_{1}$ 와 $N_{2}$ 은 각각 레이저 발진이 일어나는 하 위, 상위 에너지 준위에 위치한 전자의 상태 밀도를 의미한 다. $\sigma$ 와 $a$ 는 혼입 이온 물질의 방출 혹은 흡수 단면적(CrossSection)과 흡수 계수를 의미하며, $\tau$ 는 이온 혼입 영역과의 중첩률에 해당한다. 첨자 $e$ 와 $a$ 는 각각 방출(Emission)과 흡 수(Absorption)을 의미하며, 첨자 $p, s, B$ 는 펌프, 시드, 브릴 루앙 신호의 의미로 쓰였다. 본 연립 미분방정식은 경계조건 과 함께 수치 해석적으로 풀 수 있는데, 본 연구에서는 회귀 맞힘방법(Iterative Shooting Method)을 사용하였다. 증폭단 광섬유로 Nufern사의 YDF (PLMA-YDF-25/400)를 사용하였 을 경우 ${ }^{[67]}, 3 \mathrm{GHz}$ 선폭을 갖는 시드광의 증폭에 관한 수치 해석 결과는 아래와 같다.

Figure 11은 펌프광과 시드광이 $6 \mathrm{~m}$ 의 $\mathrm{Yb}$ 혼입 광섬유를 통해 동일한 방향으로 전파될 때 겪게 되는 출력 변화를 보 여준다. $1.20 \mathrm{~kW}$ 의 펌프광의 인가를 통해 시드광은 $1.08 \mathrm{~kW}$ 까지 증폭이 되었으며, 인가된 펌프광량에 대해서 $88.7 \%$ 의 기울기 효율(Slope Efficiency)을 가진다. 수치 해석 결과를 통 해 펌프광은 $6 \mathrm{~m}$ 길이의 증폭기를 통과하며 그 광량의 대부 분인 $99.9 \%$ 가 흡수 되었고, 시드광의 증폭 역시 충분히 포 화된 상태이므로, 선정된 $\mathrm{Yb}$ 혼입 광섬유의 길이는 적당한 것으로 판단할 수 있다. 한편, $\mathrm{SBS}$ 에 의한 후방 산란광은 $6.73 \mu \mathrm{W}$ 수준에 머물러 있으므로, 심각한 SBS 현상은 실제 관측되지 않을 것으로 예상된다. 그러나, 일반적으로 SBS에 의한 후방 산란광이 지수적으로 증가하는 양상을 보임을 고 려할 때 증폭 단계 이후, 시스템 구성상 빔 전달 광섬유 용 도로 연결될 수 있는 수동형 광섬유의 길이까지 고려해 해석 


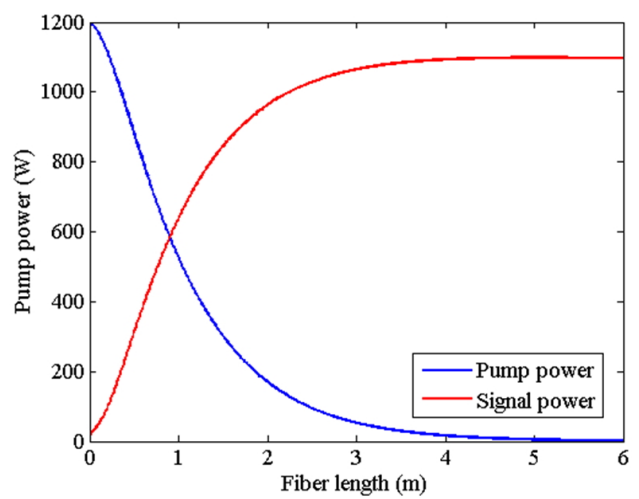

FIG. 11. Evolution of the pump and signal along a YDF of $6 \mathrm{~m}$. The parameters used in the calculation are presented in Table 2.

TABLE 2. Parameters used in the simulations of Fig. 11 and Fig. 12

\begin{tabular}{c|c|c|c}
\hline \hline Parameter & Value & Parameter & Value \\
\hline$\sigma_{\text {ep }}\left(\mathrm{m}^{2}\right)$ & $2.15 \times 10^{-24}$ & $\tau_{\mathrm{s}}$ & 0.69 \\
\hline$\sigma_{\text {ap }}\left(\mathrm{m}^{2}\right)$ & $2.35 \times 10^{-24}$ & $\mathrm{a}_{\mathrm{p}}\left(\mathrm{m}^{-1}\right)$ & 0.0081 \\
\hline$\sigma_{\text {es }}\left(\mathrm{m}^{2}\right)$ & $2.50 \times 10^{-25}$ & $\mathrm{a}_{\mathrm{s}}\left(\mathrm{m}^{-1}\right)$ & 0.0046 \\
\hline$\sigma_{\mathrm{as}}\left(\mathrm{m}^{2}\right)$ & $2.95 \times 10^{-27}$ & $\mathrm{~N}\left(\mathrm{~m}^{-3}\right)$ & $1.3 \times 10^{26}$ \\
\hline$\tau_{\mathrm{p}}$ & 0.0039 & & \\
\hline
\end{tabular}

할 필요가 있고, 또한, 시스템 구성 및 실험상 허용 오차 범 위를 고려한 안정 동작 범위를 선정할 필요가 있다. 따라서, 이를 포함하여 추가적으로 위상 변조기를 통한 선폭의 변화 와 이에 따른 후방 산란광의 출력에 대한 보다 면밀한 예측 을 해야하며, 이를 다음에서 논의하고자 한다.

Figure 12(a)는 1 5 m의 수동형 광섬유가 추가적으로 연결 된 최종단 증폭기에서 후방 산란광의 출력 양상을 보여주며, $\mathrm{Yb}$ 혼입 광섬유 및 펌프와 시드광은 앞선 수치해석과 동일 하게 설정되었다. 그림을 통해 수동형 광섬유가 길어짐에 따 라 후방 산란광의 출력이 현저히 높게 증가하는 것을 확인할 수 있다. 특히 $1 \mathrm{GHz}$ 선폭의 신호 광원을 사용한 경우에 3 $\mathrm{m}$ 길이의 수동형 광섬유가 추가로 연결되었을 시, $P_{B}$ 는 증 폭된 시드광 출력의 $0.3 \%$ 에 달하는 $3.34 \mathrm{~W}$ 까지 증가하였 다. 이는 통상적으로 일컫는 브릴루앙 후방 산란광 임계값 $30 \mathrm{~mW}$ 을 훨씬 넘어선 수치에 해당한다 ${ }^{[59]}$. 한편, SBS 현상 은 광섬유 길이뿐 아니라 신호 광원의 선폭에 크게 의존하는 데, Fig. 12(b)는 신호 광원 선폭에 따른 $P_{B}$ 의 변화를 보여준 다. 이론적으로 예측하는 바와 같이, 신호 광원의 선폭이 증 가함에 따라서 $P_{B}$ 가 확연하게 감소함을 확인할 수 있다. 따 라서, 사용 가능한 수동형 광섬유의 길이 한계는 신호 광원 의 선폭에 의해 민감하게 변하므로, 이를 고려하여 허용되는 광섬유 길이 한계를 계산하고, 그 한계 길이 미만으로 추가 적으로 연결되는 수동형 광섬유의 길이를 제한할 필요가 있 다. Figure 12(a), (b)에 따르면, 1,3 그리고 $5 \mathrm{GHz}$ 선폭의

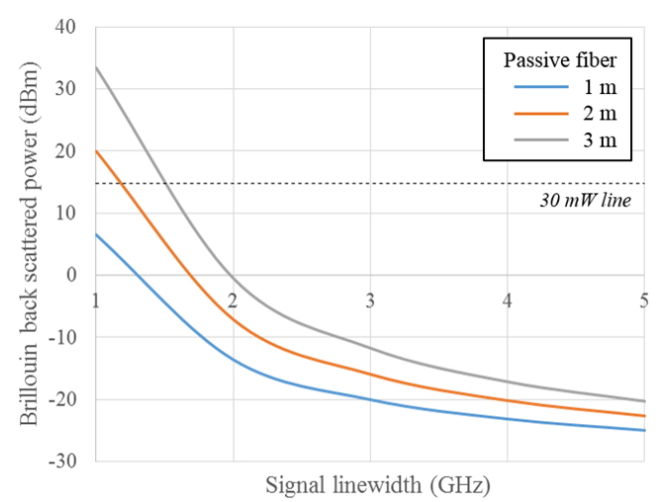

(a)

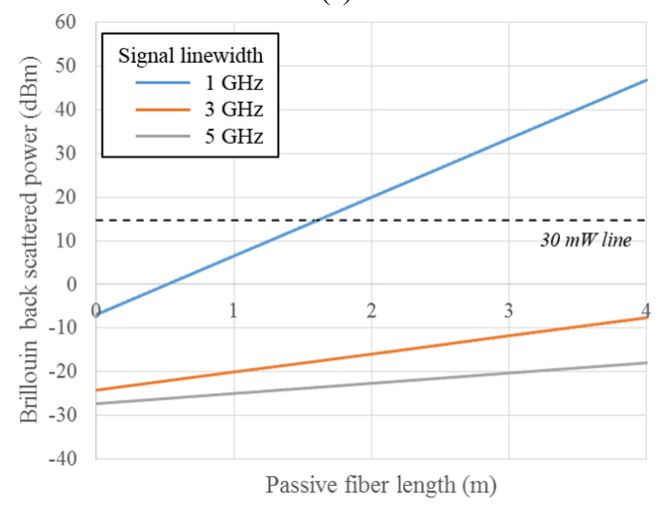

(b)

FIG. 12. SBS power with varying (a) the signal linewidth of the seed laser and (b) the passive fiber length attached to the gain fiber. The parameters used in the calculation are presented in Table 2.

신호 광원에 대하여, 수동형 광섬유의 길이 한계는 각각 1.6 , 9.4 그리고 $18 \mathrm{~m}$ 로 예측된다. 실제 시스템 설계시 이러한 수 치 해석적 예측을 기반으로 하여 충분한 안정 동작 허용 범 위를 사전에 미리 결정할 필요가 있다.

\subsection{3. $\mathrm{SBC}$ 를 위한 결합단 구성}

$\mathrm{SBC}$ 시스템의 마지막 단계인 결합단은 다수의 채널빔을 단일빔으로 결합하는 단계로, 다른 파장을 가지는 다수의 채 널빔들에 대해 광경로상의 차이를 인가할 수 있는 다양한 광 학 소자들이 빔 결합단 구성에 이용될 수 있다. 그 중에서도 반사형 회절 격자는 광손실이 적어 높은 빔 결합 효율을 기 대할 수 있어서 일반적으로 선택되는 결합 소자이다 ${ }^{[49,53-55]}$. 반사형 회절 격자를 통한 빔 결합 단계는 Fig. 13에 나타난 바와 같이 구현될 수 있다.

그림 상에서 채널의 수는 논의의 편의상 두 개로 설정되었 으나, 그 이상의 다수의 빔으로도 확장 구성될 수 있다. 그림 에서 볼 수 있듯이 서로 다른 입사각을 갖는 채널빔들은 회 절 격자를 통해 동일한 방향으로 회절되어 빔 결합이 구현된 다. 한편, 고차 회절로 인해 결합 빔에서 일정 성분이 이탈할 수 있는데, 이는 결과적으로 빔 결합 효율의 저하로 이어진 다. 따라서, 특정 차수의 회절 효율을 높일 수 있는 블레이즈 


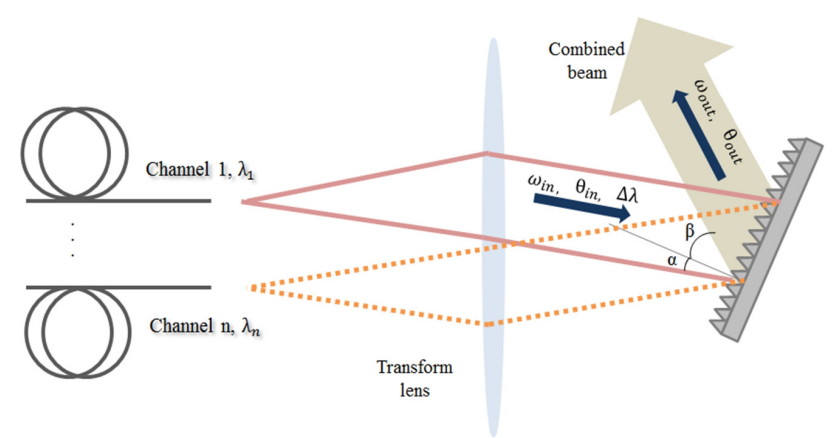

FIG. 13. Schematic of the beam combining process by a diffraction grating.

형(Blazed) 격자가 일반적으로 선택되어 의도치 않은 빔 이 탈을 최소화 할 수 있다. 최근에 보고된 다수의 빔 결합 사 례에서는 $90 \%$ 이상의 빔결합 효율이 달성된 바 있다 ${ }^{[53,54]}$.

한편, 파장 성분 별로 서로 다른 각도로 반사시키는 회절 격자의 특성상 채널빔의 각분산(Angular Dispersion)이 야기 되어 결과적으로 결합 빔 품질이 저하될 수 있다. 빔 품질은 흔히 빔 품질 인자(Beam Quality Factor)로 정량화되는데, 만 약, 이상적인 회절 격자에 대해서 회절 한계(Diffraction- Limited) 의 가우시안 스펙트럼 분포를 갖는 채널빔이 리트로우(Littrow) 각도 근처에서 입사된다고 가정한다면, 최종적으로 결합되는 빔의 빔 품질 인자 및 회절 격자 상에서의 최대 광세기는 아 래와 같은 수식으로 표현될 수 있다 ${ }^{[53]}$.

$$
\begin{aligned}
& M^{2}=\sqrt{1+\left(\frac{g \Delta \lambda \pi \omega_{i n}}{2 \lambda \cos \alpha}\right)^{2}} \\
& I_{\text {peak }}=\frac{n P}{\left(\frac{\pi \omega_{i n}^{2}}{\cos \alpha}\right)}
\end{aligned}
$$

위 수식에서 $g$ 는 격자의 밀도, $\Delta \lambda$ 는 채널빔의 선폭, $\omega_{\text {in 는 }}$ 채널빔의 반지름, $a$ 는 채널빔이 격자 소자의 수직 방향과 이 루는 입사각에 해당한다(Fig. 13 참조). $\omega_{\mathrm{in}}$ 은 엄밀히 말해 시 준된(Collimated) 채널빔의 빔허리(Beam Waist) 지점에서의 빔 반지름에 해당하나, 격자 소자에 도달한 시점의 빔 반지 름과 큰 차이가 없는 것으로 가정되었다. 즉, 수식 (9), (10) 은 시준된 채널빔이 자유공간에서 회절 격자까지 전파해나 가며 겪는 발산(Divergence)이 매우 작은 근축파(Paraxial Wave)에 대해 유효함을 명시하는 바이다. 특히, 수식 (9)는 채널빔의 선폭이 현저히 증가할 경우 파장에 따라 회절 특성 이 달라지는 빔의 각분산에 의해 최종적인 빔 품질이 이상적 인 가우시안 빔의 품질 $\left(\mathrm{M}^{2}=1\right)$ 로부터 어떻게 저하되는지를 근사적으로 보여준다. 따라서, 수식에 나타난 다양한 변수인 자들의 적합한 선택과 조절을 통해 빔 품질의 저하를 최소화 하기 위한 노력이 필요하다. 수식 (9)의 두번 째 항을 구성하 는 변수인자들 중 격자의 밀도와 채널빔의 파장은 고정된 값
으로 볼 때, 빔 품질의 저하를 최소화하기 위해 조절 가능한 변수인자는 채널빔의 선폭, 채널빔의 반지름, 채널빔의 입사 각으로 볼 수 있다. 첫 번째로 각 채널빔의 선폭을 가능한 좁게 설정해 빔 품질의 저하를 줄일 수 있다. 하지만, 앞서 논의한 바와 같이 증폭단에서의 SBS 현상은 선폭이 좁을수 록 더 심하게 발생한다. 결과적으로 각 채널별 선폭은 앞서 말한 빔 품질 저하 및 SBS 발생 정도를 모두 고려한, 조정과 절충 과정을 거쳐, 전 시스템 상에서 충분한 안정적 동작 범 위를 보장해 줄 수 있는 수준에서 결정되어야 할 것이다. 두 번째로 입사되는 채널빔의 크기를 줄여 빔 품질의 저하를 줄 일 수 있다. 그러나, 수식 (10)에서 나타난 바와 같이 채널빔 의 크기가 감소될 수록 회절 격자의 한 지점에 집중되는 최 대 광세기가 증가하게 되는데, 이는 회절 격자의 불균일한 온도 상승을 야기해 후술하게 될 파면 왜곡 및 격자의 손상 을 초래할 수 있다. 따라서 회절 격자의 동작에 문제가 발생 하지 않는 수준에서 채널빔의 크기를 최소화기 위해서는, 수 식 (10)에 나타난 바와 같이 채널의 개수 및 채널 별 출력에 대한 고려가 수반되어야 할 것이다. 세 번째로 채널빔의 입 사각의 경우 입사각이 작아질수록 빔 품질의 저하를 줄일 수 있으나, Fig. 13에서 알 수 있는 바와 같이 입사각이 지나치 제 작아질 경우, 정면 반사를 유발하거나 빔 결합 시스템의 공간적 밀집도를 증가시키게 되므로, 이 또한 시스템의 안정 성 및 구성의 편리를 위해 조정과 절충 과정을 거쳐 결정되 어야 할 것이다.

한편, 채널빔의 각분산과 더불어 결합 과정에서 발생하는 파면 왜곡(Wavefront Distortion) 현상 또한 빔 품질의 저하 를 야기할 수 있다. 이는 고출력의 레이저 광에 의해 회절 격자가 열탄성적 변형(Thermoelastic Deformation)되어 야기 되는 현상으로, 회절 격자의 광학적 특성이 불균일해져 결과 적으로 결합 빔의 파면이 왜곡된다. 회절 격자의 열탄성적 변형은 회절 격자를 구성하는 물질 특성에 의해 결정되는데, 특히 온도 변화 대비 광 굴절률 변화 수치에 큰 영향을 받는 다 ${ }^{[68]}$. 기존에 보고된 파면 왜곡의 사례에 따르면, $1 \mathrm{~kW} / \mathrm{cm}^{2}$ 의 회절 한계 입사광에 대해 실리콘(Silicon) 격자의 경우 약 0.15 파(wave) ${ }^{[68]}$, 다층 유전체(Multi-layer Dielectric) 소재의 격자에서 0.2 파의 왜곡을 야기한다 ${ }^{[53]}$. 이는 수 $\mathrm{kW}$ 의 결합 빔을 고려할 경우 크게 문제가 되지 않는 수준의 왜곡량이지 만, 수십 $\mathrm{kW}$ 수준의 결합 빔을 목표로 하는 경우에는 보다 엄밀한 고려 및 그 특성 개선이 요구된다고 하겠다. 채널빔 의 직경을 크게 할 경우, 파면 왜곡 측면에서는 이점을 가지 게 되지만, 전술한 바와 같이, 회절 격자 자체의 파장 분산 특성에 의한 빔 지수 저하는 채널빔의 직경에 비례하여 커지 게 되므로, 이 또한, 조정과 절충의 과정을 거쳐 최적의 값으 로 결정되어야 할 필요가 있다. 또한, 별도의 냉각 시스템을 통해 회절 격자의 온도 변화를 조절하여, 회절 격자의 광 굴 절률 변화를 최소화하는 설계가 요구될 수 있다.

덧붙여서, 다수의 고출력 채널빔에 의한 회절 격자의 손상 가능성도 시스템 설계시 고려해야 할 요소이다. 일반적인 회 절 격자의 손상 임계값이 입력 신호광의 시간폭의 제곱근에 
비례하는 기존 연구 결과를 고려할 때 ${ }^{[69]}$, 본 논문에서 다루 고 있는 연속광 동작 영역에서는 회절 격자의 손상 가능성이 매우 낮다고 볼 수 있다. 하지만, 이미 보고된 ns 펄스의 빔 결합 사례와 더불어 ${ }^{[70,71]}$, 더욱 짧은 펄스의 빔 결합이 시도 되는 현 연구 흐름을 고려할 때, 회절 격자의 손상 가능성이 $\mathrm{SBC}$ 시스템 설계 과정에서 갖는 상대적인 중요성은 앞으로 더욱 커질 것으로 예상된다.

전술한 바와 같이 입력단, 증폭단, 결합단의 최적화된 설계 를 통해 $\mathrm{SBC}$ 레이저 시스템은 단일 광섬유 레이저의 출력을 현저히 상회하는 고출력의 빔을 발진할 수 있다. 최근 보고 된 $30 \mathrm{~kW}$ 의 고출력 레이저 발진 사례와 더불어 ${ }^{[62]}$, 많은 연 구 기관 및 산업체의 노력을 통해 향후 더욱 높은 출력의 레 이저가 속속히 시연될 것으로 예상된다.

\section{V. 결 론}

본 논문을 통해 고출력 광섬유 레이저의 기술 개괄 및 그 발전 현황을 논의하였다. 전술한 바와 같이 이득매질인 $\mathrm{Yb}$ 이온 혼입 광섬유의 우수성과 더불어 이중 클래딩 구조 광섬 유 및 종렬 펌핑 기술 등에 의해 최근 20 여 년간 광섬유 레 이저의 가용 최대 출력은 $\mathrm{kW}$ 급을 넘어 $20 \mathrm{~kW}$ 급에 이르는 수준까지 성장했다. 이는 비선형 현상 및 광섬유의 손상 가 능성과 같은 광섬유 레이저의 출력 제한 요소에 대한 면밀한 고려가 수반되었기 때문에 달성된 결과로 볼 수 있다.

본 논문 전반부에서는 상기 출력 제한 요소들에 대한 이론 적 설명과 이를 완화하기 위한 기술 현황에 대해 논의하였 다. 그러나, 이와 같은 현상들은 광섬유의 출력에 비례해 더 욱 심하게 발생한다는 점에서 현 수준을 뛰어 넘는 광섬유 레이저의 출력 증대와 그 기술의 지속적 발전을 위해서는 이 분야에 대한 보다 심도 높은 연구 노력이 수반되어야 할 것 으로 생각된다. 이는 광섬유 레이저 물질의 특성 고도화 및 신물질 개발과 또한, 신개념의 레이저 시스템 기술, 비선형 현상 억제 기술 개발 등을 포함하는 보다 특성화되고 체계적 인 개발 노력을 말한다. 본 논문 후반부에서 개괄적으로 논 의된 다중 빔 결합 기술 역시 단일 광섬유 레이저의 출력 제 한을 극복하기 위한 또다른 대체 방안이 될 수 있을 것으로 기대한다. $\mathrm{CBC}$ 기술과 $\mathrm{SBC}$ 기술이 현재 다중 빔 결합 기술 중 가장 많은 주목을 받고 있는데, 특히 상대적으로 구현이 간편하고, 시스템의 안정성이 높은 $\mathrm{SBC}$ 기술을 중심으로 다 중 빔 결합 레이저 시스템의 각 단계별 구성 요소에 대해서 좀더 세부적인 기술적 쟁점들을 논의하였다.

이미 단일 광섬유 레이저의 출력 수준을 상회하는 수십 $\mathrm{kW}$ 의 결합 빔을 성공적으로 발진시킨 최근 연구 사례에서 볼 수 있듯이 ${ }^{[62]}$, 다중 빔 결합 기술의 적용을 통해 고출력 광섬유 레이저 시스템은 이미 새로운 발전 방향으로 나아가 고 있다. 특히, 효과적인 SBS 및 비선형 현상 억제와 모드 불안정 현상에 관한 더욱 심도 있는 연구, 다중 빔 결합 광 섬유 레이저 시스템의 최적화 과정 연구 등을 통해, 향후 고 출력 광섬유 레이저 시스템 기술은 더욱 안정적이고 더 높은
출력의 빔을 발진시킬 수 있을 것으로 기대된다. 이를 통해 수많은 관련 과학, 기술 및 산업적 응용 분야의 발전도 함께 이루어질 것으로 확신한다. 본 연구단을 비롯한 국내외의 광 섬유 레이저 분야 관련 연구자의 부단한 연구와 노력을 통 해, 광섬유 레이저 분야의 지속적인 성장과 발전이 있기를 진심으로 고대하면서 본 논의를 맺고자 한다.

\section{감사의 글}

본 연구는 두산 DST의 지원을 받아 수행되었습니다. 또한, 서울대학교 소속의 저자들은 한국연구재단(2014R1A1A2059418), 산업통상자원부(10040429), 서울대학교 반도체공동연구소 및 두뇌한국 21 플러스의 추가적인 연구지원에 감사를 표합니다.

\section{References}

1. V. Mizrahi, D. J. DiGiovanni, R. M. Atkins, S. G. Grubb, Y. Park, and J.-M. P. Delavaux, "Stable single-mode Erbium fiber-grating laser for digital communication," IEEE J. Lightwave Technol. 11, 2021-2025 (1993).

2. L. G. Luo, P. L. Chu, and H. F. Liu, "1-GHz optical communication system using chaos in Erbium-doped fiber lasers," IEEE Photon. Technol. Lett. 12, 269-271 (2000).

3. Q. Peng, A. Juzeniene, J. Chen, L. O Svaasand, T. Warloe, K.-E. Giercksky, and J. Moan, "Lasers in medicine," Rep. Prog. Phys. 71, 1-28 (2008).

4. N. M. Fried and K. E. Murray, "High-power Thulium fiber laser ablation of urinary tissues at $1.94 \mu \mathrm{m}$," J. Endourol. 19, 25-31 (2005).

5. S. Son, H. Park, and K. H. Lee, "Automated laser scanning system for reverse engineering and inspection," Int. J. Mach. Tools Manuf. 42, 889-897 (2002).

6. T. Pfister, L. Büttner, J. Czarske, H. Krain, and R. Schodl, "Turbo machine tip clearance and vibration measurements using a fibre optic laser Doppler position sensor," Meas. Sci. Technol. 17, 1693-1705 (2006).

7. M. D. Perry, B. C. Stuart, P. S. Banks, M. D. Feit, V. Yanovsky, and A. M. Rubenchik, "Ultrashort-pulse laser machining of dielectric materials," J. Appl. Phys. 85, 6803-6810 (1999).

8. A. N. Samant and N. B. Dahotre, "Laser machining of structural ceramics-a review" J. Eur. Ceram. Soc. 29, 969-993 (2009).

9. D. J. Richardson, J. Nilsson, and W. A. Clarkson, "High power fiber lasers: current status and future perspectives," J. Opt. Soc. Am. B 27, B63-B92 (2010).

10. J. C. Knight, "Photonic crystal fibers and fiber lasers," J. Opt. Soc. Am. B 24, 1661-1668 (2007).

11. C. Jauregui, J. Limpert, and A. Tünnermann, "High-power fibre lasers," Nat. Photonics 7, 861-867 (2013).

12. R. Paschotta, J. Nilsson, A. C. Tropper, and D. C. Hanna, "Ytterbium-doped fiber amplifiers," IEEE J. Quantum Electron. 33, 1049-1056 (1997).

13. M. E. Fermann and I. Hartl, "Ultrafast fiber laser technology," IEEE J. Sel. Top. Quantum Electron. 15, 191-206 (2009). 
14. Y. Jeong, J. K. Sahu, D. N. Payne, and J. Nilsson, "Ytterbiumdoped large-core fiber laser with $1.36 \mathrm{~kW}$ continuous-wave output power," Opt. Express 12, 6088-6092 (2004).

15. Y. Jeong, J. K. Sahu, D. N. Payne, and J. Nilsson, "Ytterbiumdoped large-core fibre laser with $1 \mathrm{~kW}$ of continuous-wave output power," Electron. Lett. 40, 470-471 (2004).

16. Y. Jeong, A. J. Boyland, J. K. Sahu, S. Chung, J. Nilsson, and D. N. Payne, "Multi-kilowatt single-mode Ytterbiumdoped large-core fiber laser," J. Opt. Soc. Korea 13, 416-422 (2009).

17. Y. Jeong, J. Nilsson, J. K. Sahu, D. N. Payne, R. Horley, L. M. B. Hickey, and P. W. Turner, "Power scaling of singlefrequency Ytterbium-doped fiber master-oscillaotr poweramplifier sources up to $500 \mathrm{~W}$," IEEE J. Sel. Top. Quantum Electron. 13, 546-551 (2007).

18. E. Stiles, "New developments in IPG fiber laser technology," in Proceedings of the 5th International Workshop on Fiber Lasers (2009).

19. Y. Jeong, L. A. Vazquez-Zuniga, S. Lee, and Y. Kwon, "On the formation of noise-like pulses in fiber ring cavity configurations," Opt. Fiber Technol. 20, 575-592 (2014).

20. L. A. Vazquez-Zuniga and Y. Jeong, "Power-scalable, subnanosecond mode-locked erbium-doped fiber laser based on a frequency-shifted-feedback ring cavity incorporating a narrow bandpass filter," J. Opt. Soc. Kor. 17, 177-181 (2013).

21. L. A. Vazquez-Zuniga and Y. Jeong, "Wavelength-tunable, passively mode-locked erbium-doped fiber master-oscillator incorporating a semiconductor saturable absorber mirror," J. Opt. Soc. Kor. 17, 117-129 (2013).

22. L. A. Vazquez-Zuniga, H. Kim, Y. Kwon, and Y. Jeong, "Adaptive broadband continuum source at 1200-1400 nm based on an all-fiber dual-wavelength master-oscillator power amplifier and a high-birefringence fiber," Opt. Express 21, $7712-7725$ (2013).

23. S. Lee, L. A. Vazquez-Zuniga, D. Lee, H. Kim, J. K. Sahu, and Y. Jeong, "Comparative experimental analysis of thermal characteristics of ytterbium-doped phosphosilicate and aluminosilicate fibers," J. Opt. Soc. Kor. 17, 182-187 (2013).

24. T. Yao, J. Ji, and J. Nilsson, "Ultra-low quantum-defect heating in Ytterbium-doped Aluminosilicate fibers," IEEE J. Lightwave Technol. 32, 429-434 (2014).

25. J. Limpert, F. Röser, T. Schreiber, and A, Tünnermann, "High-power ultrafast fiber laser systems," IEEE J. Sel. Top. Quantum Electron. 12, 233-244 (2006).

26. J. W. Dawson, M. J. Messerly, R. J. Beach, M. Y. Shverdin, E. A. Stappaerts, A. K. Sridharan, P. H. Pax, J. E. Heebner, C. W. Siders, and C. P. J. Barty, "Analysis of the scalability of diffraction-limited fiber lasers and amplifiers to high average power," Opt. Express 16, 13240-13266 (2008).

27. K. Park and Y. Jeong, "A quasi-mode interpretation of acoustic radiation modes for analyzing Brillouin gain spectra of acoustically antiguiding optical fibers," Opt. Express 22, $7932-7946$ (2014).

28. A. Kobyakov, M. Sauer, and D. Chowdhury, "Stimulated
Brillouin scattering in optical fibers," Adv. Opt. Photon. 2, 1-59 (2010).

29. A. Liu, "Suppressing stimulated Brillouin scattering in fiber amplifiers using nonuniform fiber and temperature gradient," Opt. Express 15, 977-984 (2007).

30. L. Zhang, S. Cui, C. Liu, J. Zhou, and Y. Feng, "170 W, single-frequency, single-mode, linearly-polarized, Yb-doped all-fiber amplifier," Opt. Express 21, 5456-5462 (2013).

31. N. Yoshizawa and T. Imai, "Stimulated Brillouin scattering suppression by means of applying strain distribution to fiber with cabling," IEEE J. Lightwave Technol. 11, 1518-1522 (1993).

32. Y. Koyamada, S. Sato, S. Nakamura, H. Sotobayashi, and W. Chujo, "Simulating and designing Brillouin gain spectrum in single-mode fibers," IEEE J. Lightwave Technol. 22, 631-639 (2004).

33. P. D. Dragic, "Ultra-flat Brillouin gain spectrum via linear combination of two acoustically anti-guiding optical fibers," Electron. Lett. 48, 1492-1493 (2012).

34. L. Dong, "Limits of stimulated Brillouin scattering suppression in optical fibers with transverse acoustic waveguide designs," IEEE J. Lightwave Technol. 28, 3156-3161 (2010).

35. D. Nodop, C. Jauregui, F. Jansen, J. Limpert, and A. Tünnermann, "Suppression of stimulated Raman scattering employing long period gratings in double-clad fiber amplifiers," Opt. Lett. 35, 2982-2984 (2010).

36. J. Kim, P. Dupriez, C. Codemard, J.Nilsson, and J. K. Sahu, "Suppression of stimulated Raman scattering in a high power Yb-doped fiber amplifier using a W-type core with fundamental mode cut-off," Opt. Express 14, 5103-5113 (2006).

37. X. Ma, I.-N. Hu, and A. Galvanauskas, "Propagation-length independent SRS threshold in chirally-coupled-core fibers," Opt. Express 19, 22575-22581 (2011).

38. R. L. Farrow, D. A. V. Kliner, G. R. Hadley, and A. V. Smith, "Peak-power limits on fiber amplifiers imposed by selffocusing," Opt. Lett. 31, 3423-3425 (2006).

39. G. Fibich and A. L. Gaeta, "Critical power for self-focusing in bulk media and in hollow waveguides," Opt. Lett. 25, 335-337 (2000).

40. A. V. Smith and J. J. Smith, "Mode instability in high power fiber amplifiers," Opt. Express 19, 10180-10192 (2011).

41. C. Jauregui, T. Eidam, J. Limpert, and A. Tünnermann, "The impact of modal interference on the beam quality of highpower fiber amplifiers," Opt. Express 19, 3258-3271 (2011).

42. C. Jauregui, T. Eidam, H.-J. Otto, F. Stutzki, F. Jansen, J. Limpert, and A. Tünnermann, "Physical origin of mode instabilities in high-power fiber laser systems," Opt. Express 20, 1291212925 (2012).

43. M. Karow, H. Tünnermann, J. Neumann, D. Kracht, and P. Weßels, "Beam quality degradation of a single-frequency Yb-doped photonic crystal fiber amplifier with low mode instability threshold power," Opt. Lett. 37, $4242-4244$ (2012).

44. T. Eidam, C. Wirth, C. Jauregui, F. Stutzki, F. Jansen, H.-J. Otto, O. Schmidt, T. Schreiber, J. Limpert, and A. Tünnermann, 
"Experimental observations of the threshold-like onset of mode instabilities in high power fiber amplifiers," Opt. Express 19, 13218-13224 (2011).

45. A. V. Smith and J. J. Smith, "Increasing mode instability thresholds of fiber amplifers by gain saturation," Opt. Express 21, 15168-15182 (2013).

46. C. Jauregui, H.-J. Otto, F. Stutzki, F. Jansen, J. Limpert, and A. Tünnermann, "Passive mitigation strategies for mode instabilities in high-power fiber laser systems," Opt. Express 21, 19375-19386 (2013).

47. S. Naderi, I. Dajani, T. Madden, and C. Robin, "Investigation of modal instabilities in fiber amplifiers through detailed numerical simulations," Opt. Express 21, 16111-16129 (2013).

48. K. R. Hansen, T. T. Alkeskjold, J. Broeng, and J. Laegsgaard, "Thermally induced mode coupling in rare-earth doped fiber amplifiers" Opt. Lett. 37, 2382-2384 (2012).

49. T. Y. Fan, "Laser beam combining for high-power, highradiance sources," IEEE J. Sel. Top. Quantum Electron. 11, 567-577 (2005).

50. S. J. Augst, J. K. Ranka, T. Y. Fan, and A. Sanchez, "Beam combining of ytterbium fiber amplifiers," J. Opt. Soc. Am. B 24, 1707-1715 (2007).

51. W. Liang, N. Satyan, F. Aflatouni, A. Yariv, A. Kewitsch, G. Rakuljic, and H. Hashemi, "Coherent beam combining with multilevel optical phase-locked loops," J. Opt. Soc. Am. B 24, 2930-2939 (2007).

52. S. J. McNaught, P. A. Thielen, L. N. Adams, J. G. Ho, A. M. Johnson, J. P. Machan, J. E. Rothenberg, C.-C. Shih, D. M. Shimabukuro, M. P. Wacks, M. E. Weber, and G. D. Goodno, "Scalable coherent combining of kilowatt fiber amplifers into a 2.4-kW beam," IEEE J. Sel. Top. Quantum Electron. 20, 0901008 (2014).

53. T. H. Loftus, A. M. Thomas, P. R. Hoffman, M. Norsen, R. Royse, A. Liu, and E. C. Honea, "Spectrally beamcombined fiber lasers for high-average-power applications,' IEEE J. Sel. Top. Quantum Electron. 13, 487-497 (2007).

54. C. Wirth, O. Schmidt, I. Tsybin, T. Schreiber, R. Eberhardt, J. Limpert, A. Tünnermann, K. Ludewigt, M. Gowin, E. ten Have, and M. Jung, "High average power spectral beam combining of four fiber amplifiers to $8.2 \mathrm{~kW}$," Opt. Lett. 36, 3118-3120 (2011).

55. C. Wirth, O. Schmidt, I. Tsybin, T. Schreiber, T. Peschel, F. Brückner, T. Clausnitzer, J. Limpert, R. Eberhardt, A. Tünnermann, M. Gowin, E. ten Have, K. Ludewigt, and M. Jung, "2 $\mathrm{kW}$ incoherent beam combining of four narrow-linewidth photonic crystal fiber amplifiers," Opt. Express 17, 1178-1183 (2009).

56. D. R. Drachenberg, O. Andrusyak, G. Venus, V. Smirnov, J. Lumeau, and L. B. Glebov, "Ultimate efficiency of spectral beam combining by volume Bragg gratings," Appl. Opt. 52, 7233-7242 (2013).

57. A. Sevian, O. Andrusyak, I. Ciapurin, V. Smirnov, G. Venus, and L. Glebov, "Efficient power scaling of laser radiation by spectral beam combining,” Opt. Lett. 33, 384-386 (2008).
58. G. P. Agrawal, Applications of Nonlinear Fiber Optics, 2nd ed. (Academic Press, Boston, USA, 2007).

59. V. Khitrov, K. Farley, R. Leveille, J. Galipeau, I. Majid, S. Christensen, B. Samson, and K. Tankala, "kW level narrow linewidth $\mathrm{Yb}$ fiber amplifiers for beam combining" Proc. SPIE 7686, 76860A-1-76860A-8 (2010).

60. S. Hädrich, T. Schreiber, T. Pertsch, J. Limpert, T, Peschel, R. Eberhardt, and A. Tünnermann, "Thermo-optical behavior of rare-earth-doped low-NA fibers in high power operation," Opt. Express 14, 6091-6097 (2006).

61. D. N. Payne, Y. Jeong, J. Nilsson, J. K. Sahu, D. B. S. Soh, C. Alegria, P. Dupriez, C. A. Codemard, V. N. Philippov, V. Hernandez, R. Horley, L. Hickey, L. Wanzcyk, C. E. Chryssou, J. A. Alvarez-Chavez, and P. W. Turner, "Kilowattclass single-frequency fiber sources," Proc. SPIE 5709, 133-141 (2005).

62. http://www.laserfocusworld.com/articles/2015/03/lockheedmartin-s-30-kw-fiber-laser-weapon-disables-truck-from-a-m ile-away.html

63. http://www.qphotonics.com/Fiber-Coupled-Single-ModeLaser-Diodes/

64. J. B. Coles, B. P.-P. Kuo, N. Alic, S. Moro, C.-S. Bres, J. M. C. Boggio, P. A. Andrekson, M. Karlsson, and S. Radic, "Bandwidth-efficient phase modulation techniques for stimulated Brillouin scattering suppression in fiber optical parametric amplifiers," Opt. Express 18, 18138-18150 (2010).

65. A. Flores, C. Robin, A. Lanari, and I. Dajani, "Pseudo- random binary sequence phase modulation for narrow linewidth, kilowatt, monolithic fiber amplifiers," Opt. Express 22, 17735-17744 (2014).

66. A. V. Harish and J. Nilsson, "Optimization of phase modulation with arbitrary waveform generators for optical spectral control and suppression of stimulated Brillouin scattering," Opt. Express 23, 6988-6999 (2015).

67. http://www.nufern.com/pam/optical_fibers/933/PLMA-YD F-25_400-VIII/

68. P. P. Lu, A. L. Bullington, P. Beyersdorf, S. Traeger, and J. Mansell, R. Beausoleil, E. K. Gustafson, R. L. Byer, and M. M. Fejer, "Wavefront distortion of the reflected and diffracted beams produced by the thermoelastic deformation of a diffraction grating heated by a Gaussian laser beam," J. Opt. Soc. Am. A 24, 659-668 (2007).

69. B. C. Stuart, M. D. Feit, S. Herman, A. M. Rubenchik, B. W. Shore, and M. D. Perry, "Nanosecond-to-femtosecond laserinduced breakdown in dielectrics," Phys. Rev. B 53, 1749-1761 (1996).

70. O. Schmidt, C. Wirth, D. Nodop, J. Limpert, T. Schreiber, T. Peschel, R. Eberhardt, and A. Tünnermann, "Spectral beam combination of fiber amplified ns-pulses by means of interference filters," Opt. Express 17, 22974-22982 (2009).

71. M. Fabert, A. D.-Berthelemot, V. Kermène, and A. Crunteanu, "Temporal synchronization and spectral combining of pulses from fiber lasers Q-switched by independent MEMS micro-mirros," Opt. Express 20, 22895-22901 (2012). 